\title{
Bonds and Brands: Foundations of Sovereign Debt Markets, 1820-1830
}

\author{
MARC FLANDREAU AND JUAN H. FLORES
}

How does sovereign debt emerge? In the early nineteenth century, intermediaries' market power and prestige served to overcome information asymmetries. Relying on insights from finance theory, we argue that capitalists turned to intermediaries' reputations to guide their investment strategies. Intermediaries could in turn commit or else they would lose market share. This sustained the development of sovereign debt. This new perspective is backed by archival evidence and empirical data, and it suggests why strong but undemocratic states could borrow.

"A good name is worth more than a gem."

Yiddish proverb

$\mathrm{H}$ ow does sovereign debt emerge and become sustainable, when there are information asymmetries, when countries have reasons to renege on their commitments, when intermediaries have incentives to cheat investors? History provides an instance where this happened. In the early nineteenth century, at a time when information asymmetries were enormous, one Gregor MacGregor managed to sell to the public the securities of a fictitious state known as "Poyais." A sovereign debt "bubble" developed. A number of the new bond issues failed miserably, but the episode did lay the ground for the emergence of a successful sovereign debt market.

By studying the experiment, this article provides a new perspective on the sustainability of sovereign debt and the reasons why states

The Journal of Economic History, Vol. 69, No. 3 (September 2009). (C) The Economic History Association. All rights reserved. ISSN 0022-0507.

Marc Flandreau is Professor, The Graduate Institute, Geneva, P.O. Box 136, 1211 Geneva 21, Switzerland; and Research Fellow, Centre of Economic and Policy Research, London. E-mail: marc.flandreau@graduateinstitute.ch. Juan H. Flores is Assistant Professor, Department of Economic History, University of Geneva, 40, bd du Pont-d'Arve, CH-1211 Geneva 4, Switzerland. E-mail: juan.flores@unige.ch.

Financial support from Chaire de finances internationales, Sciences Po (Paris), Universidad Carlos III (Madrid), and the Bank of France is gratefully acknowledged. This article developed over a number of years and places. The authors are grateful to archivists from ING-Baring, Guildhall Library, Rothschild London, and Euronext (Paris Bourse) for their kind cooperation. We especially thank James Khedari for excellent research assistance. Larry Neal helped locate early editions of Wetenhall's Course of Exchange, and in many other ways, providing feedback, insights, and more. Lars Frederik Oksendal kindly provided data for Danish bonds quotes in Hamburg. We are grateful to European Historical Economics Society Lund Conference participants (June 2007) where this article was first presented, to seminar and conference participants at the University of Venezia Summer School (September 2007), the University of 
honor their commitments. Our approach to the "sovereign debt puzzle" (i.e., why do countries repay their debts?) differs from previous explanations. We argue that market power helped overcome information asymmetries and sustained the development of sovereign debt. Given the dearth of information about sovereign borrowers, capitalists relied on intermediaries' reputations to guide their investments.

The model we consider is the following: when borrowers accessed global capital markets through the agency of a "big name" underwriter, investors were prepared to pay a higher price. Leading banks thus owned a "brand" that could grant market access on favorable terms. Since they earned their income from their sustained ability to deliver safety to their customers, they had strong reasons to make a careful use of their reputation: a wrong choice would reverberate on market share and therefore, on profitability. In other words, the reason why borrowers' credibility problems were not just translated to intermediaries is to be found in market power.

Conversely, because prestigious banks controlled access to liquidity, borrowers had incentives to refrain from defaulting, and this contributed to protect the credibility of intermediaries. Finally, because borrowers faced switching costs when shopping around, incumbent names managed to retain market predominance. The outcome was a highly hierarchical, highly concentrated, and highly persistent global bond market, which turned out to be sustained by its very monopolization.

This view represents a departure from current research in history, economics, and political science. In particular, we demonstrate the relevance of microeconomics and modern finance theory for the study of international financial organization. While recent works discuss the relation between sovereign debt and good governance (embedded in

\footnotetext{
Zürich (September 2007), the Princeton University Conference on Globalization (September 2007), the Harvard Center for Latin American Studies Seminar and the Harvard Business School Seminar (both October 2007), the Workshop on Economic History at the University Carlos III (October 2007), the First Latin American Economic History Congress in Montevideo, (December 2007), the Economic History Seminar at Oxford University (March 2008), the Financial History Seminar at Rothschild (April 2008), and the Economics Department Seminar at Tel Aviv University (May 2008). Olivier Accominotti, Vincent Bignon, Jorge Braga de Macedo, Lawrence Broz, Forrest Capie, Youssef Cassis, Jerry Cohen, Barry Eichengreen, Rui Esteves, June Flanders, Giorgio Fodor, Jeff Frieden, Norbert Gaillard, Aurora Gomez, Harold James, John James, Clemens Jobst, Carlos Marichal, Aldo Musaccio, Larry Neal, Pilar NoguèsMarco, Joaquim Oliveira Martins, Patrick O'Brien, Hillel Rapoport, Giuseppe Tattara, Stefano Ugolini, Jeff Williamson, and Frédéric Zumer volunteered comments and insights. They should be thanked for their contribution but absolved from our shortcomings. The suggestions of three referees are gratefully acknowledged. Detailed comments and editorial advice from Philip Hoffman proved most helpful.
} 
institutions such as constitutions, commitments, or the rule of law), we suggest looking at intermediaries' market shares. Finally, while modern wisdom holds that globalization and the spread of information go hand in hand, we find that ignorance, or rather, the monopolization of knowledge, were decisive factors in the development of financial globalization in this early era.

To guide the reader through a substantial amount of historical and theoretical material, the argument in this article is organized as follows. We begin by surveying the recent literature on the history of sovereign debt. This will serve to outline the novelty of our emphasis on intermediaries' reputation. We next introduce our theory and articulate its relation to modern finance literature. After providing readers with the necessary historical background, we test our theory by looking at the 1820 s sovereign debt boom-bust cycle, and underwriters' prestige in the $1820 \mathrm{~s}$. We then demonstrate how intermediaries' prestige enabled investors to screen borrowers and argue that concerns over reputation aligned the incentives of bondholders and leading merchant bankers. After a statistical test of our argument, our conclusion offers suggestions for future research and emphasize that current views on the "democratic advantage" and constitutional constrain may be incomplete.

\section{THE SOVEREIGN DEBT PUZZLE IN THEORY AND HISTORY}

Sovereign lending involves two problems. Several lenders deal with one borrower, which creates difficulties with contracting and collective action. In addition, the immunity of the sovereign borrower only adds to the trouble. These problems are so severe that in an influential article, Jeremy Bulow and Kenneth Rogoff have argued that sovereign lending is not feasible if financial markets are complete and perfectly competitive. Governments can borrow in one market, invest the proceeds in another, and default.

Subsequent research has relaxed some of the underlying assumptions behind these results. Bulow and Rogoff suggest that punishment may sustain sovereign debt. ${ }^{1}$ In that spirit, Kris Mitchener and Marc Weidenmier argue that before 1914, "supersanctions" (gunboats, trade sanctions, or external control) provided the credible threat that made sovereign debt possible.

\footnotetext{
${ }^{1}$ Bulow and Rogoff, "Sovereign Debt." Another solution to the sustainability problem is monopoly power on the lender's side. See Chowdry, "International Lending"; Wright, "Reputations"; and Flandreau, "Home Bias."
} 
One problem with the gunboat argument is that although a substantial part of military interventions were conducted by the United States, London was actually the main market for sovereign debt. Earlier wisdom from D. C. M. Platt emphasized how reluctant British authorities were to wield political power in order to enforce payment of private debts. ${ }^{2}$ Subsequent British prime ministers saw the hazards of transforming the navy into a collection agency. ${ }^{3}$ Philip Ziegler writes about Prime Minister Canning, who rejected intervention in defaulting Latin American countries during the period this article considers, that "not only would he not send a gunboat to manifest British displeasure, he declined to allow British diplomats and consular agents to bring pressure on the defaulters. If British investors chose to risk their money overseas, then it was their own funeral if they lost it."

Funerals provide opportunities to congregate, and another theme in the sovereign debt literature is how creditors coordinate their actions. Edwin Borchard has discussed the framework for creditors' action, and William Wynne has provided case studies. There is much recent focus on the experience of the London based Corporation of Foreign Bondholders (or CFB), created 1868. Barry Eichengreen and Richard Portes study bonds issued during the 1920s and show that organized British bondholders realized higher ex post rates of return than their unorganized American counterparts. Paolo Mauro, Nathan Sussman and Yishay Yafeh conclude from CFB reports that "the CFB may have had an easier time than any comparable body would have today." Rui Esteves argues that over the period 1870-1914, CFB sponsored settlements outperformed other arrangements in terms of duration and recovery ratios. ${ }^{5}$

A third group of papers dealing with sovereign debt follow up on Douglass North and Barry Weingast's claim that parliamentary control

\footnotetext{
${ }^{2}$ Mitchener and Weidenmier, "Corollary" and "Supersanctions"; Platt, Finance, pp. 34-53; and Lipson, "Security."

${ }^{3}$ More recently, Tomz, Cooperation, p. 153, has argued that the correlation between default and military intervention is spurious because "defaulters tended to be involved in other disputes (civil wars, territorial conflicts, tort claims) that attracted the attention of major powers."

${ }^{4}$ Ziegler, Sixth Great Power, pp. 107-08. Regarding trade sanctions, we find that Latin America was too attractive a market for merchant bankers to support sanctions in parliament. "The South American market presented by far greater advantage to the British merchant than any other be at present had intercourse with." The Times, 21 May 1830. For an interesting argument linking monopoly in trade finance and repayment enforcement, see Vizcarra, "Guano."

${ }_{5}^{5}$ Borchard, Insolvency, vol. I; Wynne, Insolvency, vol. 2; Eichengreen and Portes, "Settling Defaults" and "After the Deluge"; Mauro, Sussman, and Yafeh, Emerging Markets, p. 162; and Esteves, "Quis custodiet?"
} 
provides opponents to default with a veto point. ${ }^{6}$ In an early-nineteenthcentury variant, Niall Ferguson suggests that during the 1810s and $1820 \mathrm{~s}$, the House of Rothschild favored borrowers with democratic restraint, an argument previously made by Karl Polanyi. ${ }^{7}$ In 1818 Nathan de Rothschild wanted to make a loan to Prussia conditional upon introduction of a form of parliamentary control. But archival evidence shows that in the end, the actual security was a mere mortgage on royal domains. ${ }^{8}$ Other historians have claimed that borrowing in London enabled Prussian policymakers to escape the constitutional concessions that a domestic loan would have forced.'

We remark that during the period under study, many faithful and successful sovereign borrowers were in fact countries that lacked constitutional checks: reactionary or autocratic Russia, Austria, and Prussia, as well as their political satellites such as the Kingdom of Naples. Another successful borrower, Brazil, was a monarchy with less than perfect parliamentary control. ${ }^{10}$ While there were other countries such as Denmark and France that in the 1820s might have fit North and Weingast's story about sovereign borrowing, their constitutional argument does not work for most countries.

A last family of studies emphasizes imperfect information. When investors cannot observe the true characteristics of borrowers, they only lend if certain observable policies or rules are implemented. Michael Bordo and Hugh Rockoff portray the gold standard exchange rate regime as a "good housekeeping seal of approval." Michael Tomz claims that lenders learn about countries by observing their commitment to repay. ${ }^{11}$ Both emphasize the importance of contextual inference: adhering to the rules in dire times earns more reputation than doing it in easy periods.

\footnotetext{
${ }^{6}$ North and Weingast, "Constitutions." Supporters include Root, "Ancien Régime"; and Schultz and Weingast, "Democratic Advantage," for Ancien Régime France, Razaghian, "Credibility," for early-nineteenth-century United States, and Summerhill, "Sovereign Commitment," for nineteenth-century Brazil (between 1824 and 1889). Sussman and Yafeh, "Meiji," provide a contrarian view. Stasavage, Public Debt and "Partisan Politics," emphasizes the role of partisan politics as opposed to constitutions.

${ }^{7}$ Polanyi, Great Transformation; and Ferguson, World's Banker, pp. 131-43. Sylla, "Credit Rating," p. 21, provides a similar interpretation.

${ }^{8}$ Ferguson, World's Banker, p. 132. Ferguson makes a similar claim about a Portuguese loan, which would have "once again demonstrated [Nathan's] willingness to lend to a constitutional regime, as the Portuguese king had accepted a Spanish-style constitution drafted by the Lisbon Cortes on his return from Brazil in 1822" (p. 142). As we will see, however, this loan was not brought out by the House of Rothschild.

${ }^{9}$ Rothschild Archive, 000/401. According to Gille, Rothschild, vol. I, p. 202, Frankfurt's burgomaster Smidt noted in 1820: "Prussia would have had to give up its regime long ago if the house [of Rothschild] had not helped it to survive. See also Kehr, "Preussichen Bürokratie."

${ }^{10}$ Summerhill, "Sovereign Commitment."

${ }^{11}$ Bordo and Rockoff, "Gold Standard"; and Tomz, Cooperation.
} 
However, during the period under study, the gold standard existed only in Britain - and as a recent reintroduction. Other countries had paper, silver, or bimetallic standards. ${ }^{12}$ The value of an exchange rate regime as a signal of good faith also suffers from a free riding problem: nobody "owns" a convertibility rule, and countries that pretend they behave well merely by adhering to convertibility debase the rule.

Another assumption that is implicit in Bordo and Rockoff and explicit in Tomz is that the set of investors is made of more or less helpless, atomistic, identical individuals who cannot see beyond the veil of policy rules. ${ }^{13}$ But Marc Flandreau and Frédéric Zumer have shown that late-nineteenth-century investors were sophisticated. They priced bonds to reflect fundamentals. Flandreau's study of the emergence of rating techniques in the 1890s also suggests that investors were not at all "atomistic agents" because of the role of certain intermediaries, such as Crédit Lyonnais in France, in the process of information gathering and processing. ${ }^{14}$ But what de we know of the early nineteenth century?

\section{A SKETCH OF THE ARGUMENT}

This article argues that sovereign borrowers could access markets because financial intermediaries could monitor them effectively, and the reason why intermediaries would monitor them effectively is because the intermediaries themselves were not an amorphous lot.

To begin with, there were higher rank underwriters, who had the ability to signal good loans to uninformed investors. They could credibly commit to monitoring borrowers, because they were concerned with retaining their reputation. They could also prevent countries from borrowing too much, by suspending market access. Conversely, they could provide attractive borrowing terms to countries that behaved well. Borrowers could thus credibly commit to repay their debts, for if they did not behave, they would have to rely on less prestigious intermediaries, who could not offer comparable loan terms. Therefore, our story is about imperfect competition, information asymmetries, and market structure.

So let us begin by exploring the various mechanisms through which banks became "associated" with certain countries through the process of public offering. Based on our reading of secondary sources and

\footnotetext{
${ }^{12}$ On bimetallism, see Flandreau, Glitter of Gold.

${ }^{13}$ Tomz, Cooperation, p. 233; Mosley, Global Capital, p. 258; and Mauro, Sussman, and Yafeh, Emerging Markets, p. 99. Cassis, "Financial Institution," underlines the importance of English investment trusts for foreign and colonial finance.

${ }^{14}$ Flandreau and Zumer, Global Finance; and Flandreau, "Caveat."
} 
numerous original sovereign debt contracts in merchant bank archives, we have formed a picture of "typical" international sovereign bond issues in Europe in the early nineteenth century. ${ }^{15}$ First, the relevant authority ("the government") had to decide to raise fresh capital. The impetus to do so may have come from bankers. The government then had to choose the characteristics of the securities (maturity of the bonds, coupon, etc.), as well as select a method for picking an intermediary or agent ("the underwriter"). That agent could be one or several syndicated banks and venture capitalists who were prepared to bear the risks of buying the bonds from the issuer and selling them to the public. ${ }^{16}$ The degree of cooperation among lenders ("syndication") was not as formalized then as it would become later.

Two main adjudication systems emerged. The first was a sealed bid auction where a number of selected syndicates were invited to submit formal tenders in closed envelopes. The other method we call an "open bargaining" system. A number of bankers were informally invited to participate or sometimes invited themselves. Tenders were communicated to the government, and counteroffers were made. Competitors occasionally merged, or split. The winning group was eventually chosen. ${ }^{17} \mathrm{~A}$ critical difference between the two systems was the degree of control regarding the identity of the winner. If borrowers had a preferred intermediary but wanted to extract the highest price, authorities might prefer open bargaining. On the other hand, open bargaining enabled bidders to observe each others' actions and may have led to more conservative offers.

The previous stage was "contracting." Next was "distributing." Selling securities to investors required facilities, the employment of clerks, and the transfer of funds. A bank (or possibly group of banks if the issue occurred on several markets) was chosen to serve as the window. Bonds were paid in installments, and installments were spread over weeks or months. Only after investors settled the last installment did governments receive the cash. But underwriting contracts could anticipate deliveries, with bankers assuming the risk. Finally, someone had to take care of coupon payments, which involved managing transfers from the borrowers to the creditors. The risks and revenues of

\footnotetext{
${ }^{15}$ Secondary sources include Jenks, Migration; Gille, Rothschild, vols. I and II; and Suzuki, Loan Issues. Dawson, First Debt Crisis; and Costeloe, Bonds, provide perspectives on the early period.

${ }^{16}$ The separation of stages suggested here is heuristic. Bidders competed on borrowing terms and on the pattern of underwriting contracts simultaneously. "Bond characteristics selection" and "auction" stages overlapped.

${ }^{17}$ We believe that reasons for choosing alternative auctioning methods should be a topic for future research.
} 
the last two operations were much smaller than those from the first, but leads and lags could cause trouble.

All these tasks need not be performed by a single institution, but if one did, the signal to the market was that the bank sponsored the issue. This responsibility appears to have been meaningful, since there were cases where distributing banks emphasized to the public that they had only a partial association with a given issue. In other cases, banks could participate in the underwriting of a given security but kept their involvement secret.

In practice, two main forms of cooperation between bankers and governments were observed. At one extreme, one intermediary did it all and served as contractor, window, and coupon payer. We will call such a bank a "sponsor." At the other extreme, the bank acted as simple window and coupon payer. We will call such a bank an "issuer."

Consider now an ideal world where information is perfect and markets competitive. Governments sell bonds to atomistic investors. To make matters simple, they sell sterling denominated 5 percent perpetual securities. These securities are distributed through banks. Everybody knows how good borrowers are. Differences in bond prices reflect known default risks. Securities are sold at their known equilibrium value, minus the intermediary's fee. The fee is charged competitively and equal to the marginal costs of distribution. In this case, intermediaries are essentially ATM machines.

However, the world was not at all like that and as a result, intermediaries had a critical role to play. Recall the case of MacGregor, who sold the bonds of a country that did not exist (Poyais). In real life, there were governments that knew how good or bad they were, but if they were bad, they had reasons to claim they were good. And there were intermediaries who had some information about borrowers (if nothing else, they had an idea of how much information was available). But they earned fees from selling securities: like governments, they had incentives to claim that bad issuers were really good ones - or even that they existed when they did not as did the infamous MacGregor.

This opens the door to strategic behavior by both borrowers and intermediaries. One way to explore this is to observe how fees are being charged. However, current archival limitations do not enable us to study them. Fortunately, there is another way to approach the problem. Modern finance literature recognizes that issuers and underwriters of corporate securities deliberately underprice their issues. This underpricing is known as the Initial Public Offering discount, but is not limited to genuine IPOs. More broadly, researchers have identified the existence of a "price run-up" after an issue occurs. They 
have also suggested that price run-ups shed light on underlying information asymmetries.

Recent research on IPO discounts and price run-ups in corporate debt markets interprets the underpricing phenomenon as a "lemon's premium," which has to be given to investors for the issue to succeed. ${ }^{18}$ In a world where there are both informed and uninformed agents, underpricing compensates uninformed investors for the risks of trading against superior information. In these models, the extent of underpricing increases as the information asymmetry between informed and uninformed agents widens. ${ }^{19}$

In principle, therefore, prestigious underwriters would be able to secure lower price run-ups because they could reduce information asymmetries. Following the same logic, information asymmetries for bonds issued by bad banks are large and the discount should, in principle, be big. However, competition is important here. When there are many prestigious houses, competition does indeed ensure that issue prices remain close to the secondary market prices. But if the prestigious underwriter is a monopoly firm, it can extract a rent for the service of labelling debt issues. Meanwhile, free entry opens the door to mediocrity. Informed speculators are attracted by the volatility of bad issues. They move in, reducing the IPO discount (this is known as the "hot issue" problem). ${ }^{20}$ With one prestigious firm and free entry for mediocre underwriters, one would expect a separating equilibrium to emerge, with stable, low yield, high run-up, serious issues, underwritten by the prestigious house on the one hand, and riskier, higher yield, volatile and low average run-ups issues underwritten by anybody else on the other. ${ }^{21}$

How then do investment banks secure a good reputation? Thomas Chemmamur and Paolo Fulghieri develop a relevant model in which financial intermediaries' reputation for veracity mitigates the moral hazard problem in information production. Prestigious underwriters who might be tempted to overprice in order to generate short-term gains do not do so because it would damage their reputation. Over the long

\footnotetext{
${ }^{18}$ Rock, "New Issues"; Ritter, "Going Public"; and Allen and Faulhaber, "Signalling."

${ }^{19}$ Carter and Manaster, "Initial Public Offerings"; and Chemmamur, "Pricing."

${ }^{20}$ In the historical context of this study, initial subscription of securities only required a down payment of about 10 percent of the value of the bond, after which the purchasing certificate or "scrip" could be traded, so that "scrip" was an option and invited speculators.

${ }^{21}$ Ritter, "Hot Issues"," makes this claim in a model of speculative manias, where there is segmentation between the market for "hot" and "cold" issues. Prestigious underwriters abstain from the market for "hot" issues, while lesser ones compete for them. As a result, there is less underpricing in the market for hot issues.
} 
run, Richard Carter, Frederick Dark, and Ajai Singh show that issues managed by prestigious houses outperform those managed by ordinary ones. $^{22}$

Previous historians have noted the existence of such a discount in nineteenth-century sovereign bond markets and suggested that setting of the discount was a critical part of the business of underwriting. In what follows, we use the insights from financial economics to interpret the evidence we have on primary market pricing. ${ }^{23}$

Our argument has parallels in earlier research, including our own work. ${ }^{24}$ Gary Gorton, for instance, has invoked insights from Douglas Diamond's incomplete information model to suggest that intermediaries' reputation formation may have deterred American banks from becoming "wildcats" (i.e., issue banknotes and vanish in the open air afterwards) in the free banking era. ${ }^{25}$ The mechanism rests on a mixture of repeat play and monopoly power. A bank with a large market share behaves responsibly, because the one shot gains of cheating are offset by future losses in market share. Business historians have emphasized the role of prestige, competition, reputation, and strategic selection of customers. ${ }^{26}$ Another parallel exists with the U.S. corporate financial history, where Bradford DeLong has emphasized the role of J. P. Morgan's "adding value" to U.S. firms on whose boards his representatives sat. ${ }^{27}$ Later on, Morgan and other New York bankers

\footnotetext{
${ }^{22}$ Chemmamur and Fulghieri, "Reputation." An early contribution is Hayes, "Investment Banking." Beatty and Ritter, "Reputation," show that underwriters whose offerings underperform lose market share.

${ }^{23}$ There is anecdotal historical evidence on sovereign IPO underpricing in Gille, Rothschild, vol. I. Relevant references in financial economics include Logue, "Pricing"; Ibbotson, "New Issues"; and Miller and Reilly, "Mispricing," who discuss the "IPO puzzle" for corporate securities.

${ }^{24}$ Flandreau, "Moral Hazard," notes the incidence of relationship banking on sovereign debt crisis management, and Flandreau, "Caveat," argues that Crédit Lyonnais' rating techniques were developed in the 1890s to raise the bank's profile and take advantage of the damage the Argentine crisis did to Barings in 1890. Flores, Le leader, "Lombard Street," and "Baring Crisis," emphasizes the importance of the flawed signal that Barings sent to the market by distributing Argentine securities.

${ }^{25}$ Gorton, "Reputation Formation"; and Diamond, "Reputation Acquisition." On wildcat banking in the United States, see Dwyer, "Wildcat Banking."

${ }^{26}$ Ziegler, Sixth Great Power, p. 107, argues: "If a loan backed by Barings' ended in such abject failure, who would trust their judgment in the future?" A similar point is made by Carosso, Morgans, who argues that in the late nineteenth century, when J. P. Morgan became an "up and coming" house in international bond issues, concerns over reputation was a primary reason why they turned down certain accounts. On reputation, see also Jenks, Migration, passim; Landes, Bankers and Pashas, pp. 39-40; Suzuki, Loan Issues; Mosley, Global Capital, pp. 258-63; and Hoffman, Postel-Vinay, and Rosenthal, Surviving.

${ }^{27}$ DeLong, “J. P. Morgan's Men.” In the mechanism DeLong emphasizes, Morgan associates would ensure that proper management decisions would be taken, but he also emphasizes reputational concerns and market share.
} 
would get involved in sovereign debt, although marginally only until the interwar. ${ }^{28}$ In a similar vein, Ilse Mintz quotes contemporary reports that in New York in the 1920s, "bonds were bought by Tom, Dick, and Harry ... without reference to the solidity or the solvency of the bonds . . ., but entirely on the faith of the house issuing them in New York." 29 Closer to our period, James Riley's account of the late-eighteenthcentury Amsterdam market for sovereign debt raises similar issues. Since information was scarce, investors did not screen borrowers but instead looked at intermediaries. ${ }^{30}$ Evidence from 1790 indicates that investors distinguished among the intermediaries on the basis of the confidence they inspired, which arose from the "care which those houses take to only introduce in the market solid loans, and to monitor the respect of all forms." ${ }^{31}$ Thus, we strongly suspect that the principles we are about to spell out have validity beyond the specific period we are looking at.

\section{THE FIRST FOREIGN DEBT BOOM AND BUST: 1820-1826}

During the eighteenth century, a foreign exchange network consolidated around Amsterdam, where the embryo of a sovereign debt market developed. ${ }^{32}$ Following the French wars, London supplanted Amsterdam as the center of a highly integrated European system. Other important regional or national centers included Paris, Hamburg, Frankfort, Vienna, Milan, Madrid, Cadiz, and Naples. Cross listing of securities and partnership between correspondents facilitated arbitrage operation. ${ }^{33}$

After 1815 sovereign debt markets were initially stirred by indemnity loans and war debt settlements among former allies. ${ }^{34}$ Figure 1 shows international issues accelerating after 1820. Editions of Fortune's Epitome, a leading market handbook, show only one non-British sovereign security outstanding in London in 1820, but 23 in

\footnotetext{
${ }^{28}$ Lewis, America's Stake.

${ }^{29}$ Mintz, Deterioration, p. 81. See also Lewis, America's Stake, p. 382; and Winkler, Autopsy, p. 89.

30 "First and foremost was the reputation that a firm acquired only after several years of prudent enterprise in which even the suggestion of rash business was absent. A house also had to meet standards concerning the scale of its activities ... Investors also preferred firms meeting these and other standards." Riley, Amsterdam, p. 39.

${ }^{31}$ Ibid., pp. 42-43. The insider was T. Cazenove, a prominent London broker.

${ }^{32}$ Ibid; and Dawson, First Debt Crisis, p. 15.

${ }^{33}$ Buist, At Spes; Gille, Rothschild, vol. I, pp. 79-80; and Neal, Rise.

${ }^{34}$ These took the form of short-term lending, with banks holding sovereign debt in their books and stabilization loans to European governments. See Gille, Rothschild, vol. I.
} 


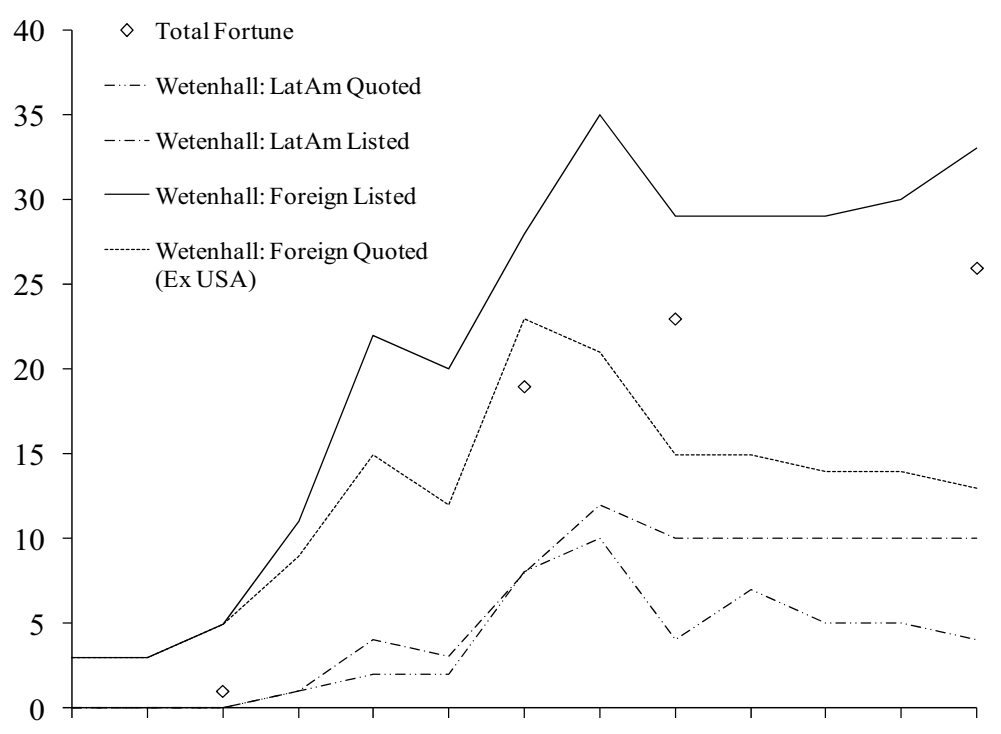

1818181918201821182218231824182518261827182818291830

\section{FigURE 1 \\ NUMBER OF FOREIGN GOVERNMENTS' STOCKS TRADED IN LONDON (Ex USA), 1818-1830}

Source: Authors computations from subsequent editions of Fortune's Epitome; and Wetenhall, Course of Exchange. The Fortune observation from 1830 is from the 1833 edition.

1826..$^{35}$ Similarly, James Wetenhall's Course of the Exchange has quotes for foreign government securities rising from almost nil in 1820 to 35 in $1825 .^{36}$ This sovereign debt boom of the 1820 s has sometimes been called the first "Latin American" debt crisis, but governments outside Latin America were involved as well.

Colombia's 6 percent loan started things off. ${ }^{37}$ The same year saw loans to Chile, to Peru, to the imaginary "Poyais," as well as to Spain, Russia, Prussia, Denmark, and the Kingdom of Naples. In the fall of 1822, political complications in Spain rocked prices (Figure 2), but they subsided when the Congress of Verona gave France a mandate to

\footnotetext{
${ }^{35}$ We restrict our attention to non-British sovereign bonds issued through London IPOs. This excludes French 5 percent rentes, and U.S. 3 percent and U.S. 6 percent, that came to London through cross listing. See Fortune's Epitome, 1820.

${ }^{36}$ Quotations abroad reflected this trend. The Paris Cours des effets commerçables had one foreign security listed in 1820, but twelve in 1825 .

${ }^{37}$ It was issued at the price of 84 (yielding 7.14 percent) and entirely sold (Dawson, First Debt Crisis). On Colombian prospectuses, see Rothschild Archives, Box: XIII/230/78-95.
} 


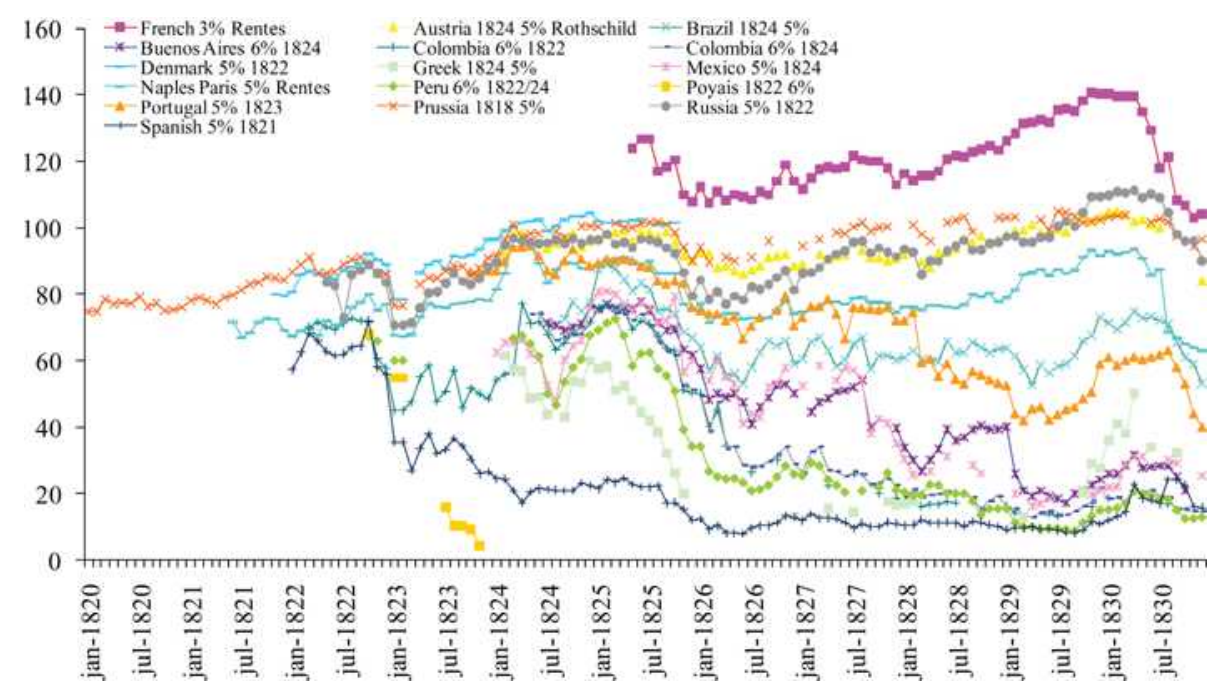

FIGURE 2

BOND PRICES DURING THE 1820-1826 BOOM-BUST CYCLE

Note: Prices have been normalized to 5 percent coupon.

Source: Wetenhall, Course of Exchange.

intervene. ${ }^{38}$ The constitutional Cortes government issued a final loan in 1823 , but when the absolute monarchy was restored, the king refused to recognize "odious" Cortes debts. Later the same year, there were two more loans, to Austria and Portugal, and then in 1824, Buenos Aires, Brazil, Colombia, Mexico, Greece, and the Kingdom of Naples borrowed, followed by Brazil, Mexico, Greece, Denmark, and Guatemala in 1825 .

In July 1825 "foreign funds" (as the equities issued by foreign governments were known in London) began to slide. In December 1825, the collapse became part of a financial storm known as "the Panic." It reached its apex on December 11th, when a run on London banks led to numerous failures. The Bank of England came close to suspend specie payments, and Latin American and South European securities plummeted (Figure 2). The collapse reverberated on financial intermediaries, some of whom had underwritten large amounts of sovereign debt such as Goldschmidt (which went under in February

\footnotetext{
${ }^{38}$ Held in October 1822, it was the last of the series of international get-togethers initiated by the Congress of Vienna. It met to consider action against the liberal government in Spain, see Nicolle, "Ouvrard."
} 
1826) and Barclay, Herring, Richardson and Co. (which crumbled in July). ${ }^{39}$

Meanwhile, sovereign defaults were spreading. Peru was first to suspend payment, in April 1826, followed by Colombia in May. More defaults accumulated within the next two years: Chile, Greece, Mexico, Guatemala, Buenos Aires, and Portugal. By the end of 1829, the sovereign debt issues of the early 1820 s had turned into a disaster. All the Latin American countries, except Brazil, and all Southern European countries, except the Kingdom of Naples, were in arrears.

Three elements are worth emphasizing. First, the sovereign defaults did not precede but rather followed the intermediaries' failures. Second, there were substantial co-movements between certain bond prices. Third, not all securities were hit to the same extent: Prussia, Austria, Russia, the Kingdom of Naples, and, to some extent, Brazil fared relatively well and managed to escape the effects of this "southern states" debt crisis.

Earlier research discussed the crisis of 1825 from various vantage points. Bertrand Gille and Larry Neal provide general accounts. Frank Dawson gives an exhaustive perspective on Latin American debts. These and other studies discuss the reasons for the initial enthusiasm and eventual collapse, relying on contemporary opinions. ${ }^{40}$ The usual suspects include investors' appetite for risk, which ran up against reality; excess liquidity, which was tripped up by restrictive monetary policy by the Bank of England; or connected lending (contractors of the Latin American bonds being sometimes promoters of mining companies), which foundered beneath unsustainable debt burdens. ${ }^{41}$ Bailout expectations (Britain had sponsored independence in Latin America and recognized the new republics in October 1822) ran head into Lord Canning's insistence that Britain's foreign policy was

\footnotetext{
${ }^{39}$ The collapse in sovereign debt had left Goldschmidt with a $£ 0.4$ million shortfall, or 30 percent of the bank's total liabilities. According to Gille, Rothschild, vol. I, p. 159, Nathan Rothschild would have offered support to B. A. Goldschmidt, but the day after, he died, "of chagrin." The trustees appointed to deal with the situation included several merchant bankers and financiers including Rothschild and Barclay and Gurney, and Mr. Richardson, See Guardian, Thursday, February 23. For Barclay, Herring, Richardson and Co., see Gille, Rothschild, vol. I, pp. 159-160 and 162; and Costeloe, Bonds, p. 22.

${ }^{40}$ Gille, Rothschild, vol. I; Neal, "Financial Crisis"; and Dawson, First Debt Crisis. Other sources include Marichal, Century; and Costeloe, Bonds.

${ }^{41}$ Ferns, Britain and Argentina; Jenks, Migration; and Platt, "Foreign Finance." Doubleday, Financial History; and Neal, "Financial Crisis." Chateaubriand, quoted by Gille (Rothschild, vol. I, p. 110) blamed irrational exuberance. Ouvrard, a French banker, (also quoted by Gille, ibid., p. 156) blamed specie exports of numéraire to the New World that caused monetary contraction.
} 
not subservient to the bondholders. ${ }^{42}$ And R. Fulford, for his part, blames the "volatile and unaccountable nature of man."43

In this article, we emphasize the relevance of information asymmetries. We already mentioned the Poyais loan. Other swindles included loans issued with the complicity of the borrowing countries' ministers in London who "forgot" to secure approval of the respective governments. ${ }^{44}$ The press was also corrupt with sellers of securities paying journalists for favorable coverage. ${ }^{45}$ But even the rare dependable sources did not provide much information. The two leading London stock market compendia, Thomas Mortimer's Every Man his Broker and Thomas Fortune's Epitome of the Stocks and Public Funds (known as Fortune's Epitome), did report in detail about British stocks. But for the more exotic instruments such as foreign bonds the content was shockingly thin. ${ }^{46}$ Figure 3 shows the Chilean, Neapolitan and Portuguese sections of Every Man. Only in the case of the Kingdom of Naples are we treated with an estimate of a somewhat vague "total debt." Judging from the direct evidence that investors had on borrowers' positions, one would conclude that investors could not tell how governments were doing. ${ }^{47}$ But as Figure 3 shows, the name of the underwriter was included. The rest of this article will demonstrate that this was equivalent to a rating, because prestigious names were an encouragement to buy.

\section{INTERMEDIARIES' PRESTIGE IN THE 1820S: EMPIRICAL EVIDENCE}

"Prestige" and "reputation" in underwriting are notoriously difficult to measure. R. B. Carter and S. Manaster rely on the "starring order" on stock offering "tombstone" announcements that are published in the

\footnotetext{
${ }^{42}$ Doubleday, Financial History; Gille, Rothschild, vol. I; Ziegler, Sixth Great Power; and Dawson, First Debt Crisis, p. 35. An intriguing paper by Giorgio Fodor challenges the notion of a "bubble." The crash, he argues, was not preceded with a genuine boom, for many securities never found a market. His account suggests (although he does not use that language) that Latin American debts were a lemon market that never really became a bubble.

${ }^{43}$ Fulford, Glyn's, p. 108.

${ }^{44}$ Jenks, Migration; Dawson, First Crisis; Mathew, "First Anglo-Peruvian Debt"; and Fodor "Boom."

${ }^{45}$ In 1826, in the midst of the crisis, the young Benjamin Disraeli was hired to argue against the existence of a price collapse. Buckle and Monnypenny, Disraeli, chap. 5; and Fodor "Boom."

${ }^{46}$ See Flandreau, "Caveat," for a discussion of how much information would be available to later investors.

${ }^{47}$ Compare this with the late situation described in Flandreau, "Caveat"; and Flores, "Information Asymmetries."
} 
NEAPOLITAN.

Capital 26,175,000 sterling. (or ducats $36,000,000$ ) boeds in decats. Exebange fixed at frases 4.40 per ducat, and fraves 25.65 per pound sterling. Interest 5 per cent. per asDum.

Dirideads payable half-yearly on the lst of January and Ist of July, at Naples, Paris, ot

at Mr. N. M. Rotbschild's, in Iondon. At the latter place with difference of exchange abd commission, and in Paris with commission oely. Brought out in 1821 at 65 per ceat.

\section{ALSO \\ A FURTHER LOAN.}

Capital $£ 2,500,000$ sterling. in 25,000 boeds of $\mathbf{f 1 0 0}$ each ; isterest at 5 per cent. per atnem. - Nigociated in 1824, by Mr. N. M. Rothuchild, and lirought out at 921 per cent.

Dividends payalle balf-yearly on the 1st of Febraary and lst of Angast at the Contractors.

(N. B. The whole debs is 1822 about f18,000,000 sterliog.)
PORTUGUESE.

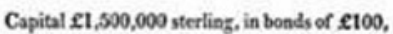
c250, e500, and 21000 : interest 5 per cest. per ansum.-Negociated in 1823, by Messr. B. A. Goldschmidt and $\mathrm{C}_{0}$, and brought out 87 per ceat.

Dividends payable balf-yearly, on the 1st of Jane and 1st of Decenber, at the Contractors.

\section{chirdan.}

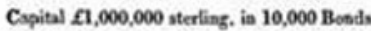
of 8100 esch: interest at 6 per ceat. per annas. Negsciated is 1822, by Measn. Hellett, Brothers, and $\mathrm{C}_{0}$, and brought ont at 70 per cent.

Dividebds payable half-yearly, on the 31st of March and 30th of September, at the Coo. tractors.

FIGURE 3

DEBTS OF THE KINGDOM OF NAPLES, PORTUGAL, AND CHILE, FROM CAREY

Source: Carey, Every Man, 1825, clippings from pp. 120, 125, 126, and 127.

press after issues have taken place. ${ }^{48}$ There were no "tombstone" announcements in the early nineteenth century, but an analogue may be contemporaries' opinion, as captured verbally in contemporary quotes, albeit "without reference to any comparative data." 49 At least verbal evidence is unanimous, making things easier. Around 1820 there were two "market leaders: Rothschilds and Barings". 50 In 1815 Barings were seen as the incumbent, but between 1815 and 1820 the Rothschilds became the market leader in sovereign debt. ${ }^{51}$ By 1830 statements by market participants recognized the Rothschilds' ascendancy and surpassing of the Barings. ${ }^{52}$ There is also agreement regarding the lower

\footnotetext{
${ }^{48}$ Carter and Manaster, "Initial Public Offerings." See also Logue, "Pricing"; Beatty and Ritter, "Reputation"; and Carter, Dark, and Singh, "Underwriter Reputation."

${ }^{49}$ Chapman, Merchant Banking, p. 17.

${ }^{50}$ Ibid., pp. $16-38$

${ }^{51}$ Ziegler, Sixth Great Power; and Gille, Rothschild, vol. I, pp. 57-77.

${ }^{52}$ See contemporaries' quotes in Gille, Rothschild, vol. I, pp. 84, 88, 105, etc. On Baring's relative decline, see Ziegler, Sixth Great Power, p. 97; and Hidy, Baring, p. 64. On its initial
} 
TABLE 1

EARLY-NINETEENTH-CENTURY GOVERNMENT BONDS LEAGUE TABLES

\begin{tabular}{|c|c|c|c|c|}
\hline & \multicolumn{4}{|c|}{ Rothschilds } \\
\hline & \multicolumn{2}{|c|}{ Number of Issues } & \multicolumn{2}{|c|}{ Amounts } \\
\hline & $\begin{array}{c}\text { Flandreau and } \\
\text { Flores } \\
\end{array}$ & Chapman & $\begin{array}{c}\text { Flandreau and } \\
\text { Flores } \\
\end{array}$ & Chapman \\
\hline $1815-1837$ & 9 & 24 & 29.8 & 105.5 \\
\hline \multirow[t]{4}{*}{ 1839-1859 } & 5 & 16 & 13.1 & 106.8 \\
\hline & \multicolumn{4}{|c|}{ Barings } \\
\hline & \multicolumn{2}{|c|}{ Number of Issues } & \multicolumn{2}{|c|}{ Amounts } \\
\hline & $\begin{array}{c}\text { Flandreau and } \\
\text { Flores }\end{array}$ & Chapman & $\begin{array}{c}\text { Flandreau and } \\
\text { Flores }\end{array}$ & Chapman \\
\hline $1815-1837$ & 3 & 5 & 10.0 & 43.2 \\
\hline \multirow[t]{4}{*}{ 1839-1859 } & 3 & 8 & 7.8 & 20.8 \\
\hline & \multicolumn{4}{|c|}{ Others } \\
\hline & \multirow{2}{*}{\multicolumn{2}{|c|}{$\begin{array}{c}\text { Number of Issues } \\
\text { Flandreau and } \\
\text { Flores } \\
\end{array}$}} & \multirow{2}{*}{\multicolumn{2}{|c|}{$\begin{array}{c}\text { Amounts } \\
\text { Flandreau and } \\
\text { Flores } \\
\end{array}$}} \\
\hline & & & & \\
\hline $1815-1837$ & \multicolumn{2}{|c|}{24} & \multicolumn{2}{|c|}{42.4} \\
\hline $1839-1859$ & \multicolumn{2}{|c|}{13} & \multicolumn{2}{|c|}{30.6} \\
\hline
\end{tabular}

Source: Authors' database and Chapman, Merchant Banking, pp. 16-38.

rank of ordinary, yet nonetheless serious merchant banking firms, such as Wilson and Co., Frederick Huth and Co., Hullett Brothers and Co., Barclay, Herring, Richardson and Co., Lizardi and Co., and Reid, Irving and Co. ${ }^{53}$

W. Megginson and K. Weiss use relative market share of the underwriters as a measure of reputation. ${ }^{54}$ Table 1 provides information on the number and amount of sovereign issues underwritten or sold by Rothschilds, Barings, and other banks from a variety of secondary sources. ${ }^{55}$ We also report the numbers derived from work by Stanley Chapman. Chapman relies on Fenn's Compendium (editions of 1837 and 1857), which gives details for most loans traded in London, whereas we focus on loans issued there. Chapman also includes railway bonds and a few sub-sovereign issues with sovereign guarantees. We

lead through relation to the House of Hope, the Amsterdam powerhouse, see Buist, At Spes, p. 524; Hidy, Baring, p. 53; and Gille, Rothschild, vol. I, p. 103.

${ }^{53}$ Hidy, Baring, calls them "second rank" institutions.

${ }_{55}^{54}$ Megginson and Weiss, "Venture Capitalists Certification."

${ }^{55}$ Authors' database, which uses Fenn's Compendia (1837 and 1857), Corporation of Foreign Bondholders Reports (various editions), and individual bank archives. 
have tried to stick to the narrow definition of sovereign debt. Finally, Chapman does not deal with intermediaries other than the Rothschilds and the Barings. Nevertheless, the two pictures are not inconsistent. Both our data and Chapman's does suggest that Rothschilds dominated Barings. In addition, Table 1 shows the Barings' and the Rothschilds' dominance of sovereign debt. Taken together, the two firms furnished 50 percent of the market for emerging market debt during the period 1815-1837, and 40 percent during the period 1839-1859.

A third possible criterion of banks' prestige is their capital. Modern models of industrial organization emphasize the strategic role of sunk costs and their interaction with market shares. ${ }^{56}$ Sunk costs may be used by early entrants to deter latecomers, and contribute to market leadership. Capital may be seen as a sunk cost, which provides incentives for careful decisions since banks stand to lose more if they make mistakes. ${ }^{57}$ Once again, the Rothschilds were exceptional, as Table 2 shows. In the 1820 s they had a lump-sum capital of $£ 4.37$ million and towered over their neighbors. The figure was ten times that of the runner-up - the Barings. The London Rothschilds alone were over twice as large as Barings (about $£ 0.5$ million in the $1820 \mathrm{~s}$ ).$^{58}$ The Barings bank, on the other hand, was well ahead of the lesser houses, which typically had capital under $£ 0.3$ million.

\section{GOOD BANKS DO WHAT THEY WANT, BAD BANKS DO WHAT THEY CAN}

\section{Banks and the Performance of Sovereign Debt Issues}

Based on previous discussions, we expect securities underwritten by prestigious banks to outperform others. Table 3 summarizes relevant information on emerging markets securities issued in London after 1815. The list was established on the basis of material provided in the 1820 s editions of stock market compendia. Entries are individual bonds issues, grouped by countries and organized in two parts. The upper part of the panel includes securities that were in arrears at the end of the decade, while the bottom part of the panel has those that were

\footnotetext{
${ }^{56}$ Sutton, "Market Structure."

${ }^{57}$ Michaely and Shaw, "Pricing."

${ }^{58}$ Barings' capital in the 1820 s compares with that of Amsterdam's leader, the House of Hope ( 0.5 million in 1810, then declining). The capital of the Hopes (see Buist, At Spes, pp. 520-25) had been higher in the 1790 s, precisely when the Amsterdam market was the main market for sovereign debt.
} 
TABLE 2

CAPITAL OF VARIOUS MERCHANT BANKS CIRCA 1825

\begin{tabular}{|c|c|c|c|}
\hline \multirow[b]{2}{*}{ Bank } & \multirow{2}{*}{$\begin{array}{c}\text { Date in } \\
\text { London } \\
\text { (if applicable) }\end{array}$} & \multicolumn{2}{|c|}{$\begin{array}{c}\text { Capital } \\
(\text { million } £)\end{array}$} \\
\hline & & $1810 \mathrm{~s}$ & 1820s and Beyond \\
\hline Barings & 1763 & $0.7-1.1(1815-1816)$ & 0.49 \\
\hline Rothschilds & 1805 & 1.8 & 4.37 \\
\hline Nathan (London) & 1805 & $0.75(1818)$ & $1.14(1828)$ \\
\hline Amschel (Frankfort) & Frankfort & $0.70(1818)$ & $0.8(1828)$ \\
\hline Salomon (Vienna) & Vienna & n.a. & $0.8(1828)$ \\
\hline Carl (Naples) & Naples & n.a. & $0.8(1828)$ \\
\hline James (Paris) & Paris & $0.35(1818)$ & $0.8(1828)$ \\
\hline Frederick Huth \& Co. & 1808 & n.a. & $0.3(1845)$ \\
\hline Antony Gibbs \& Sons & 1808 & & \\
\hline Brown, Shipley \& Co. & 1810 & $0.12(1815-1816)$ & $0.35(1825-1830)$ \\
\hline Frühling and Goschen & 1814 & n.a. & $0.04(1830)$ \\
\hline Glynn, Mills, and Co. & 1753 & n.a. & n.a. \\
\hline B. A. Goldschmidt & n.a. & n.a. & $0.22(1826)$ \\
\hline J. Henry Shröder \& Co. & 1818 & n.a. & $0.26(1852)$ \\
\hline Liverpool Shröder firm & n.a. & n.a. & $0.05(1839)$ \\
\hline Lizardi and Co. & n.a. & n.a. & n.a. \\
\hline Wilson and Co. & n.a. & n.a. & n.a. \\
\hline Reid, Irving and Co. & n.a. & n.a. & n.a. \\
\hline Fletcher, Alexander and Co. & n.a. & n.a. & n.a. \\
\hline
\end{tabular}

Sources: Barings: Ziegler, Sixth Great Power; Rothschilds: 1810s (Ferguson, World's Banker, p. 1039), and 1828: Gille, Rothschild, vol. I, p. 165; F. Huth: Chapman, Merchant Banking, p. 40; Gibbs and Sons; Guildhall Library (MSS 11021-96, 11107-40, 11467-74, 16869-904, 19862-89); B.A. Goldschmidt: from total liabilities at failure date (Gille, Rothschild, vol. I, p. 159), assuming capital asset ratio similar to Rothschilds. Shröeder: Roberts, Shroders, p. 39 for Liverpool, and p. 527 for London - the two houses were independent from one another.

consistently serviced during the 1820 s (and beyond) ${ }^{59}$ For each bond issue, we identify the country and issue characteristics (date, amount, yield at issue); the participants in the issue process (contractor, issuer, and where the coupon was paid); and the status of the debt (whether it was in arrears or not). ${ }^{60}$

Clearly, a great deal of careful selection was going on. The Rothschilds chased good securities and good securities only. No Rothschild loan was in arrears in 1829 , and only three issues without

\footnotetext{
${ }^{59}$ This criterion is unaffected by the precise final date. Latin American debts remained in arrears until the early 1840 s at the earliest, with occasional, short-lived, arrangements.

${ }^{60}$ Doubleday, Financial History, p. 281, has a similar table listing the issues of the 1820 s along with underwriters' names. It indicates with an asterisk the issues that were in arrears in 1847. Although Doubleday does not draw any inference, one striking feature of the table is the special performance of Rothschild deals. Gilbart, Principles, p. 59, has a related table showing the London loan issues between 1818 and 1832 along with amounts and underwriters' names.
} 
TABLE 3

UNDERWRITERS AND DEFAULT: SOVEREIGN BOND ISSUES IN LONDON DURING THE $1820 \mathrm{~S}$

\begin{tabular}{|c|c|c|c|c|c|c|c|}
\hline Country & Year & Contractor & Issuer & $\begin{array}{l}\text { Payment } \\
\text { of Coupon }\end{array}$ & $\begin{array}{l}\text { Amount } \\
(\text { million } £)\end{array}$ & $\begin{array}{l}\text { Yield } \\
\text { at } \\
\text { Issue }\end{array}$ & $\begin{array}{c}\text { Status in } \\
\text { Dec. } \\
1829\end{array}$ \\
\hline \multicolumn{8}{|c|}{ Defaulting States } \\
\hline Buenos Aires & 1824 & $\begin{array}{l}\text { Carlson, } \\
\text { Catro and } \\
\text { Robertson }\end{array}$ & $\begin{array}{l}\text { Baring } \\
\text { Brothers }\end{array}$ & $\begin{array}{l}\text { Baring } \\
\text { Brothers }\end{array}$ & 1.0 & 7.1 & $\begin{array}{l}\text { Arrears } \\
\text { since } \\
01-1828\end{array}$ \\
\hline Chile & 1822 & $\begin{array}{l}\text { Hullett, } \\
\text { Brothers } \\
\text { and Co. }\end{array}$ & $\begin{array}{l}\text { Hullett, } \\
\text { Brothers } \\
\text { and Co. }\end{array}$ & $\begin{array}{l}\text { Hullett, } \\
\text { Brothers } \\
\text { and Co. }\end{array}$ & 1.0 & 8.6 & $\begin{array}{l}\text { Arrears } \\
\text { since } \\
09-1826\end{array}$ \\
\hline Columbia & 1822 & $\begin{array}{l}\text { Herring, } \\
\text { Graham and } \\
\text { Powles }\end{array}$ & $\begin{array}{l}\text { Herring, } \\
\text { Graham and } \\
\text { Powles }\end{array}$ & $\begin{array}{l}\text { Herring, } \\
\text { Graham and } \\
\text { Powles }\end{array}$ & 2.0 & 7.1 & $\begin{array}{l}\text { Arrears } \\
\text { since } \\
05-1826\end{array}$ \\
\hline Columbia & 1824 & $\begin{array}{l}\text { B. A. } \\
\text { Goldschmidt }\end{array}$ & $\begin{array}{l}\text { B. A. } \\
\text { Goldschmidt }\end{array}$ & $\begin{array}{l}\text { B. A. } \\
\text { Goldschmidt }\end{array}$ & 4.75 & 6.8 & $\begin{array}{l}\text { Arrears } \\
\text { since } \\
01-1826\end{array}$ \\
\hline Greece & 1824 & $\begin{array}{l}\text { Loughnan, } \\
\text { Son, \& } \\
\text { Obrien's }\end{array}$ & $\begin{array}{l}\text { Loughnan, } \\
\text { Son, \& } \\
\text { Obrien's }\end{array}$ & $\begin{array}{l}\text { Loughnan, } \\
\text { Son, \& } \\
\text { Obrien's }\end{array}$ & 0.8 & 8.5 & $\begin{array}{l}\text { Arrears } \\
\text { since } \\
01-1827\end{array}$ \\
\hline Greece & 1825 & $\begin{array}{l}\text { J. \& S. } \\
\text { Ricardo }\end{array}$ & $\begin{array}{l}\text { J. \& S. } \\
\text { Ricardo }\end{array}$ & $\begin{array}{l}\text { J. \& S. } \\
\text { Ricardo }\end{array}$ & 2.0 & 8.8 & $\begin{array}{l}\text { Arrears } \\
\text { since } \\
01-1827\end{array}$ \\
\hline Guatemala & 1825 & $\begin{array}{l}\text { Barclay, } \\
\text { Herring, } \\
\text { Richardson } \\
\text { \& Co., } \\
\text { and J. A. } \\
\text { Powles \& } \\
\text { Co. }\end{array}$ & $\begin{array}{l}\text { Barclay, } \\
\text { Herring, } \\
\text { Richardson } \\
\text { \& Co., } \\
\text { and J. A. } \\
\text { Powles \& } \\
\text { Co. }\end{array}$ & $\begin{array}{l}\text { Barclay, } \\
\text { Herring, } \\
\text { Richardson } \\
\text { \& Co., } \\
\text { and J. A. } \\
\text { Powles \& } \\
\text { Co. }\end{array}$ & 1.43 & 6.8 & $\begin{array}{l}\text { Arrears } \\
\text { since } \\
02-1828\end{array}$ \\
\hline Mexican & 1824 & $\begin{array}{l}\text { B. A. } \\
\text { Goldschmidt }\end{array}$ & $\begin{array}{l}\text { B. A. } \\
\text { Goldschmidt }\end{array}$ & $\begin{array}{l}\text { B. A. } \\
\text { Goldschmidt }\end{array}$ & 3.2 & 8.6 & $\begin{array}{l}\text { Arrears } \\
\text { since } \\
10-1827\end{array}$ \\
\hline Mexican & 1825 & $\begin{array}{l}\text { Barclay, } \\
\text { Herring, } \\
\text { Richardson } \\
\text { \& Co., and } \\
\text { J. A. Powles } \\
\text { \& Co. }\end{array}$ & $\begin{array}{l}\text { B. A. } \\
\text { Goldschmidt } \\
\& \text { Co. }\end{array}$ & $\begin{array}{l}\text { B. A. } \\
\text { Goldschmidt } \\
\& \text { Co. }\end{array}$ & 3.2 & 6.7 & $\begin{array}{l}\text { Arrears } \\
\text { since } \\
10-1827\end{array}$ \\
\hline Peru & 1822 & $\begin{array}{l}\text { Thomas } \\
\text { Kinder }\end{array}$ & $\begin{array}{l}\text { Thomas } \\
\text { Kinder }\end{array}$ & $\begin{array}{l}\text { Fry \& } \\
\text { Chapman }\end{array}$ & 0.45 & 6.8 & $\begin{array}{l}\text { Arrears } \\
\text { since } \\
04-1826\end{array}$ \\
\hline Peru & 1824 & $\begin{array}{l}\text { Thomas } \\
\text { Kinder }\end{array}$ & $\begin{array}{l}\text { Thomas } \\
\text { Kinder }\end{array}$ & $\begin{array}{l}\text { Fry \& } \\
\text { Chapman }\end{array}$ & 0.75 & 7.3 & $\begin{array}{l}\text { Arrears } \\
\text { since } \\
04-1826\end{array}$ \\
\hline
\end{tabular}


TABLE $3-$ CONTINUED

\begin{tabular}{|c|c|c|c|c|c|c|c|}
\hline Country & Year & Contractor & Issuer & $\begin{array}{l}\text { Payment } \\
\text { of Coupon }\end{array}$ & $\begin{array}{l}\text { Amount } \\
(\text { million } £)\end{array}$ & $\begin{array}{l}\text { Yield } \\
\text { at } \\
\text { Issue }\end{array}$ & $\begin{array}{c}\text { Status in } \\
\text { Dec. } \\
1829\end{array}$ \\
\hline \multicolumn{8}{|c|}{ Defaulting States } \\
\hline Peru & 1825 & $\begin{array}{l}\text { Thomas } \\
\text { Kinder }\end{array}$ & $\begin{array}{l}\text { Thomas } \\
\text { Kinder }\end{array}$ & $\begin{array}{l}\text { Fry \& } \\
\text { Chapman }\end{array}$ & 0.62 & 7.7 & $\begin{array}{l}\text { Arrears } \\
\text { since } \\
04-1826\end{array}$ \\
\hline Portugal & 1823 & $\begin{array}{l}\text { B. A. } \\
\text { Goldschmidt }\end{array}$ & $\begin{array}{l}\text { B.A. } \\
\text { t Goldschmidt }\end{array}$ & $\begin{array}{l}\text { B.A. } \\
\text { Goldschmidt }\end{array}$ & 1.5 & 5.7 & $\begin{array}{l}\text { Arrears } \\
\text { since } \\
06-1828\end{array}$ \\
\hline Spain & $\begin{array}{l}1821 \\
\text { to } 1822\end{array}$ & $\begin{array}{l}\text { Haldimand } \\
\text { and Sons }\end{array}$ & $\begin{array}{l}\text { Haldimand } \\
\text { and Sons }\end{array}$ & $\begin{array}{l}\text { Haldimand } \\
\text { and Sons }\end{array}$ & 12.9 & 8.9 & $\begin{array}{l}\text { Arrears } \\
\text { since } \\
05-1824\end{array}$ \\
\hline Spain & 1823 & $\begin{array}{l}\text { James } \\
\text { Campbell }\end{array}$ & $\begin{array}{l}\text { James } \\
\text { Campbell }\end{array}$ & $\begin{array}{l}\text { James } \\
\text { Campbell }\end{array}$ & 1.4 & 16.7 & $\begin{array}{l}\text { Arrears } \\
\text { since } \\
05-1824 \\
\end{array}$ \\
\hline \multicolumn{8}{|c|}{ Non-Defaulting States } \\
\hline Austria & 1823 & Rothschild & Rothschild & Rothschild & 3.5 & 6.1 & 104.0 \\
\hline Brazil & 1824 & $\begin{array}{l}\text { Bazett, } \\
\text { Fletcher } \\
\text { and } \\
\text { T. Wilson }\end{array}$ & $\begin{array}{l}\text { Bazett, } \\
\text { Fletcher } \\
\text { and } \\
\text { T. Wilson }\end{array}$ & $\begin{array}{l}\text { Thomas } \\
\text { Wilson and } \\
\text { Co. }\end{array}$ & 1.0 & 6.7 & 73.0 \\
\hline Brazil & 1825 & Rothschild & Rothschild & Rothschild & 2.0 & 5.9 & 73.0 \\
\hline Denmark & $\begin{array}{l}1821 \\
\text { to } 1822\end{array}$ & $\begin{array}{l}\text { Haldimand } \\
\text { and Sons }\end{array}$ & $\begin{array}{l}\text { Haldimand } \\
\text { and Sons }\end{array}$ & $\begin{array}{l}\text { B.A. } \\
\text { Goldschmidt }\end{array}$ & 3.0 & 6.5 & $\begin{array}{l}\text { Fully } \\
\text { redeemed }\end{array}$ \\
\hline Denmark & 1825 & $\begin{array}{l}\text { Thomas } \\
\text { Wilson } \\
\text { and Co. }\end{array}$ & $\begin{array}{l}\text { Thomas } \\
\text { Wilson } \\
\text { and Co. }\end{array}$ & $\begin{array}{l}\text { Thomas } \\
\text { Wilson } \\
\text { and Co. }\end{array}$ & 3.5 & 4.0 & 75.1 \\
\hline Naples & 1824 & Rothschild & Rothschild & Rothschild & 2.5 & 5.4 & 98.5 \\
\hline Prussia & 1822 & Rothschild & Rothschild & Rothschild & 3.5 & 6.0 & 104.1 \\
\hline Russia & 1822 & Rothschild & Rothschild & Rothschild & 5.0 & 6.2 & 109.4 \\
\hline
\end{tabular}

the Rothschild's seal of approval escaped default: two for Denmark and one for Brazil. We have already suggested that, as a country with constitutional oversight of its financial process, Denmark did not need the Rothschild support badly, but we know that the Rothschilds 
displayed an interest in issuing them. ${ }^{61}$ The same holds for Brazil. As seen in Table 3, while the Rothschilds did not participate in the first issue, they were involved in the second one.

"Ordinary" firms such as B. A. Goldschmidt, Chapman and Fry, and Hulett Brothers could not be so choosy. They were happy to underwrite any bond that came their way, or which they could come across, and logically ended up with the defaulting ones. The only instance when a prestigious bank was associated with a default (Baring, with Buenos Aires), came when the bank had been a mere issuer, not an underwriter. The underwriter was a less prestigious firm, and Barings made it clear that they were not providing a seal of approval to the loan.

Table 4 provides a number of additional criteria to gauge the performance of the various issues. For each security, it reports: first, the issue "run-up," which is the variation (in percentage) between issue price and the first quoted price - in other words, the percentage IPO discount; second, the short-term performance or result after three months; and third, the success or failure of the issue, where failure means not finding a market. Complete subscription does not necessarily mean success. Some securities were purchased in anticipation of a quick gain, but failed to find "buy and hold" investors when speculators began to sell. ${ }^{62}$ The result was a price collapse, and in some instances speculators who could not sell stopped paying instalments. ${ }^{63}$ We finally report a measure of long-term performance (average return) computed as the internal rate of return between the issue date and the end of the decade. ${ }^{64}$ Excess returns are measured relative to a risk-free British consol investment.

The table shows that securities underwritten and issued by the House of Rothschild clearly outperformed the rest. Rothschild's issues had an average annual return ranging between 4.6 percent (Brazil 1825) and 9.6 percent (Russia 1822), versus 3.3 percent to 5.4 percent on consols. That Brazil 1825 provides the lowest yield among Rothschild-sponsored issues may reflect the fact that the association between Brazil and Rothschilds was not complete. On the other hand, Brazil is the best

\footnotetext{
${ }^{61}$ Predictably, the Rothschilds were bidding for Denmark and Gille says their offer came at a hair-breadth from winning.

${ }^{62}$ Fodor, "Boom," argues that the actual amounts collected from naive investors were tiny.

${ }^{63}$ See Fodor, "Boom," p. 14, for Peru's 1822 loan. A failed issue is identified as one where the quoted price stays below the issue price level in the three months following issue.

${ }^{64}$ The method is the same as described in Eichengreen and Portes, "Settling Defaults." To abstract from the political events of the second half of 1830, the end of the decade is taken to be in December 1829. Other, longer horizons yield essentially identical results. When a security was converted during the period, we assumed that investors subscribed to the new security.
} 
TABLE 4

PERFORMANCE OF SOVEREIGN LOANS IN LONDON DURING THE 1820S (in percent)

\begin{tabular}{|c|c|c|c|c|c|c|c|c|}
\hline Country & Year & $\begin{array}{c}\text { Coupon } \\
(\%)\end{array}$ & $\begin{array}{c}\text { Run-Up } \\
(\%)\end{array}$ & $\begin{array}{c}\text { Short } \\
\text { Term: } \\
\text { 3-month }\end{array}$ & $\begin{array}{l}\text { Placement } \\
\text { Result: } \\
\text { Success/ } \\
\text { Failure }\end{array}$ & $\begin{array}{l}\text { Rate of } \\
\text { Return } \\
\text { on Bond }\end{array}$ & $\begin{array}{l}\text { Rate of } \\
\text { Return } \\
\text { on } \\
\text { Consols }\end{array}$ & $\begin{array}{l}\text { Excess } \\
\text { Return }\end{array}$ \\
\hline \multicolumn{9}{|c|}{ Defaulting States } \\
\hline Buenos Aires & 1824 & 6 & 1.47 & -2.9 & $\mathrm{~F}$ & -12.0 & 3.2 & -15.2 \\
\hline Chile & 1822 & 6 & 9.82 & 18.57 & $\mathrm{~S}$ & -6.5 & 5.9 & -12.5 \\
\hline Columbia & 1822 & 6 & 0.3 & -1.2 & $\mathrm{~F}$ & -13.3 & 5.7 & -19.0 \\
\hline Columbia & 1824 & 6 & -2.0 & -0.3 & $\mathrm{~F}$ & -16.7 & 3.4 & -20.1 \\
\hline Greece & 1824 & 5 & 4.6 & -17.8 & F & -5.2 & 3.9 & -8.6 \\
\hline Greece & 1825 & 5 & 1.3 & -17.7 & $\mathrm{~F}$ & -7.7 & 3.5 & -11.1 \\
\hline Guatemala & 1825 & 5 & -1.37 & -9.6 & $\mathrm{~F}$ & -28.5 & 5.0 & -33.4 \\
\hline Mexican & 1824 & 5 & 6.9 & 14.7 & $\mathrm{~S}$ & -10.8 & 4.1 & -14.9 \\
\hline Mexican & 1825 & 6 & 3.6 & 0.8 & $\mathrm{~S}$ & -18.1 & 3.6 & -21.7 \\
\hline Peru & 1822 & 6 & -8.2 & -18.2 & $\mathrm{~F}$ & -15.0 & 4.9 & -20.0 \\
\hline Peru & 1824 & 6 & -4.9 & -31.7 & $\mathrm{~F}$ & -20.1 & 3.3 & -23.4 \\
\hline Peru & 1825 & 6 & -5.7 & -12.2 & $\mathrm{~F}$ & -24.4 & 4.6 & -29.0 \\
\hline Portugal & 1823 & 5 & -0.3 & 0.0 & $\mathrm{~S}$ & -3.8 & 5.1 & -8.9 \\
\hline Spain & $1821-1822$ & 5 & 2.2 & 21.9 & $\mathrm{~S}$ & -21.2 & 5.5 & -26.7 \\
\hline Spain & 1823 & 5 & -10.7 & -30.6 & $\mathrm{~F}$ & -28.0 & 5.1 & -33.1 \\
\hline \multicolumn{9}{|c|}{ States Without Default } \\
\hline Austria & 1823 & 5 & 6.40 & 6.4 & $\mathrm{~S}$ & 9.1 & 5.1 & 4.0 \\
\hline Brazil & 1824 & 5 & 2.0 & 3.7 & F & 6.5 & 3.0 & 3.6 \\
\hline Brazil & 1825 & 5 & 3.82 & 2.1 & $\mathrm{~S}$ & 4.6 & 3.6 & 1.0 \\
\hline Denmark & 1821-1822 & 5 & 3.23 & 9.5 & $\mathrm{~S}$ & 8.3 & 5.8 & 2.4 \\
\hline Denmark & 1825 & 3 & -3.33 & -4.7 & $\mathrm{~F}$ & 5.4 & 3.4 & 2.0 \\
\hline Naples & 1821 & 5 & 12.50 & 15.0 & $\mathrm{~S}$ & 7.8 & 5.7 & 2.1 \\
\hline Naples & 1824 & 5 & 0.67 & 1.8 & $\mathrm{~S}$ & 6.9 & 3.3 & 7.1 \\
\hline Prussia & 1822 & 5 & 2.83 & 6.6 & $\mathrm{~S}$ & 8.0 & 5.0 & 3.0 \\
\hline Russia & 1822 & 5 & 3.09 & 6.2 & $\mathrm{~S}$ & 9.6 & 5.4 & 4.2 \\
\hline
\end{tabular}

Source: Authors' computations from Wetenhall, Course of Exchange, and other sources.

performing Latin American issue and the only Latin American issue with a Rothschild association. Losses on securities issued by ordinary banks were enormous. Guatemala held the record (a compounded 28.5 percent annual loss), but all other securities faced dramatic negative returns - 6.5 percent for Chile, 12 percent for Buenos Aires, and 15 percent for Peru.

We now show that the market understood this ex ante. First, we note from Table 3 that yields at issue were lowest for Rothschild bonds, which is consistent with purchasers considering the Rothschild's underwriting to be a signal of future good performance. Further evidence of this understanding comes from the Rothschild issues. They 
had typically positive run-ups and tended to be fully subscribed. By contrast, there were many failed issues among the securities sponsored by ordinary intermediaries. That Rothschilds were responsible, and not the "reputation" of borrowing states becomes clear if we look at the only two issues within the non-defaulting group that failed: the first Brazilian issue and second Danish one. It turns out - tellingly - that they were not sponsored by Rothschilds. If we compare this first Brazilian issue (issued by Wilson in 1824) with the second one (issued by Rothschilds in 1825), we see that Wilson's ran up 2 percent and failed to sell out. Rothschilds ran up by 4 percent and was a success. Similarly, the Danish issue in 1825, which Rothschilds had tried to secure but which the Wilsons ultimately issued, experienced a 3.3 percent decline on the first day of trading. We conclude that investors were careful about brands. Before purchasing, they looked at labels and, not finding what they cared for, put the stuff back on the shelves.

Another way to explore the performance of Rothschild and nonRothschild offerings is to examine the relationship between prices and short-term returns (Figure 4). The horizontal axis in Figure 4 reports the risk at the issue date measured by the yield at issue premium (this is the yield at issue minus the yield on British consols on the same date) ${ }^{65}$ The vertical axis measures short-term returns or "run-ups" over the issue price, which we measure as the percentage change between the issue price and the first quoted price.

Rothschild bonds, represented by triangles, are located along a line we fitted to capture the positive relation between risk and return. That is, short-term returns from Rothschild-sponsored deals were an increasing function of the risk that was revealed to the public by setting the issue price. The Rothschilds therefore did provide their clientele of investors with returns that were proportionate to the risks involved. Second, we see that Rothschild issues are located in the north-west part of the scatter plot. This means that for any level of initial risk, Rothschild issues outperform the others. When investors could predict the short-term run-up from a Rothschild issue, a non-Rothschild one was a lottery ticket. The existence of large, predictable gains, suggests some market imperfection: we argue that Rothschilds had monopoly power in high-quality issues.

\footnotetext{
${ }^{65} \mathrm{We}$ are aware that issue prices are an imperfect indicator of market views. It is one of the reasons for our previous discussion of performance. Some contemporaries complained that spreads between good and bad securities were too small and failed to compensate investors for the risk. See, for example, Ziegler, Sixth Great Power, p. 102.
} 


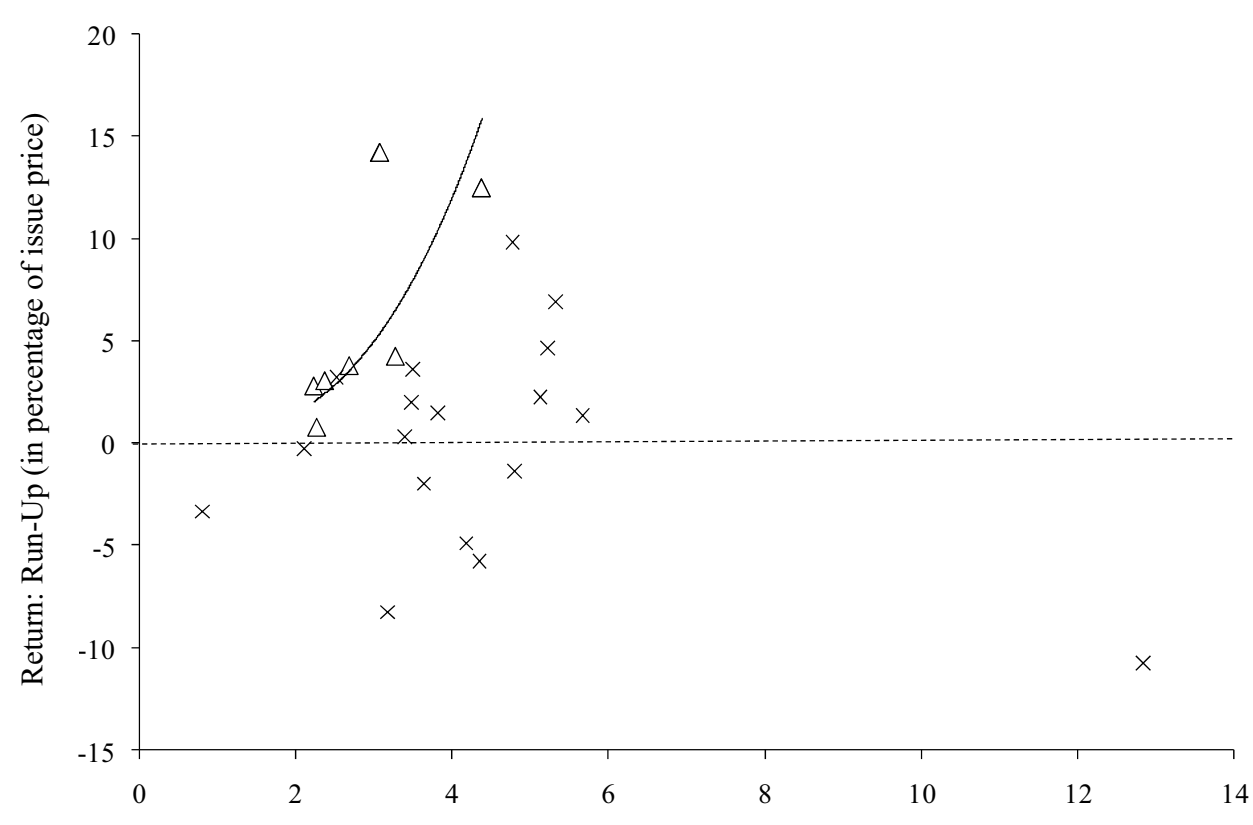

Risk: Spread at Issue over Secondary Price of Consols (in percentage points)

FIGURE 4

SHORT-TERM RISK AND RETURNS: THE ROTHSCHILD FRONTIER

Note: Rothschild issues are represented by triangles, other issues with crosses.

Source: The authors' computations.

\section{Bankers' Commitment: A Case Study}

A sponsoring bank had to work hard to secure stable and reliable returns for the securities it underwrote. There were all sorts of danger: liquidity shocks, rumors, unhappy competitors, and political rivals of the issuing governments, who could cry down securities. The bank might have to buy up shares, to keep trading going, which would require capital. That is what happened with Russia's 1822 issue, which encountered difficulties, with "much stock staying unsold," although on the face of it, it did well, with a typical "Rothschild run-up" of 3 percent. ${ }^{66}$ Presumably, someone was buying, and that someone had to be the underwriters themselves. According to Gille, Rothschild pushed the price from 81 (the price at issue) to " 84 and $85 .{ }^{.67}$ Prestigious

\footnotetext{
${ }^{66}$ Ziegler, Sixth Great Power, p. 94. See Corti, Reign, pp. 281-89, for a later incident when the Rothschilds cried down a Sardinian loan they had lost to Hambros.

${ }^{67}$ For the historical background and evidence of the Rothschilds' fine tuning of their issue run-ups, see Gille, Rothschild, vol. I.
} 
underwriters could not just walk away from their sponsored deals, for their reputation was tied to the issues' success.

An episode taking place abroad illustrates what was going on. In 1821 new Neapolitan securities were introduced by the House of Rothschild in Paris with cross listing in London. ${ }^{68}$ The new security was issued in three batches: the first, in May 1821; the second, in December 1821; the two issues of 1821 had been major successes, with prices rising continuously. The third contract, signed August 1822, was a forward underwriting agreement. It stated that the issue would occur in two tranches that would be sold at 73 and 75 in January 1823 and January 1824 respectively. An extrapolation of price trends (shown in Figure 5) suggests that Rothschilds were likely betting on further price increases. But the loan was disturbed by the events in Spain in late 1822. On the day the issue was supposed to take place, the price of the rentes was below the level at which new securities were to be sold. The Rothschilds ended up becoming sole purchasers, and the bond was not formally introduced in the market. ${ }^{69}$ At the same time, Rothschilds were intervening to support the securities, probably through forward purchases. There is a suggestion that they did so in partnership with Naples' finance minister. ${ }^{70}$ By January 1824 prices had recovered and the issue could finally be unloaded.

Problems were renewed with the collapse of Latin American securities, which took their toll on Neapolitan bonds. There was a risk of contagion. Investors sold Neapolitan bonds, forcing the Rothschilds to step in again. The 1826 balance sheet of the Paris branch (dated June 1826) shows Neapolitan bonds representing 15 percent of assets. That amounted to one-fifth of the 1824 London issue and was an amount comparable to Barings' capital. ${ }^{71}$ James de Rothschild wrote to Charles in Vienna that if it "had not been for their efforts," Neapolitan funds would be trading much lower and perhaps "the discredit could have been complete." ${ }^{, 72}$ We conclude that out of concern

\footnotetext{
${ }^{68}$ In what follows, we use quotations for the so-called "Falconet debts," which evidence suggests was used as benchmark for settling transaction on other instruments. Data (available upon request) show that quotations on Falconet debts were consistent with other sterling or franc denominated Neapolitan rentes when they are both available.

${ }^{69}$ From Great Britain Parliament, Select Committee, p. 267, "Some Revolution took place, [. . .] and if it had not been that my grandfather had paid the installment and kept the stock, the government would never have got their money."

${ }^{70}$ Gille, Rothschild, vol. I., p. 97.

${ }^{71}$ The asset side was $£ 3.8$ million of which $£ 0.5$ million was Neapolitan bonds. Gille, Rothschild, vol. I, pp. 164-65.

${ }^{72}$ Idem. In October 1827 Rothschild offered to buy future coupons at par, in effect selling cheap insurance against default, see Gille, Rothschild, vol. I., p. 168. There was also diplomatic
} 


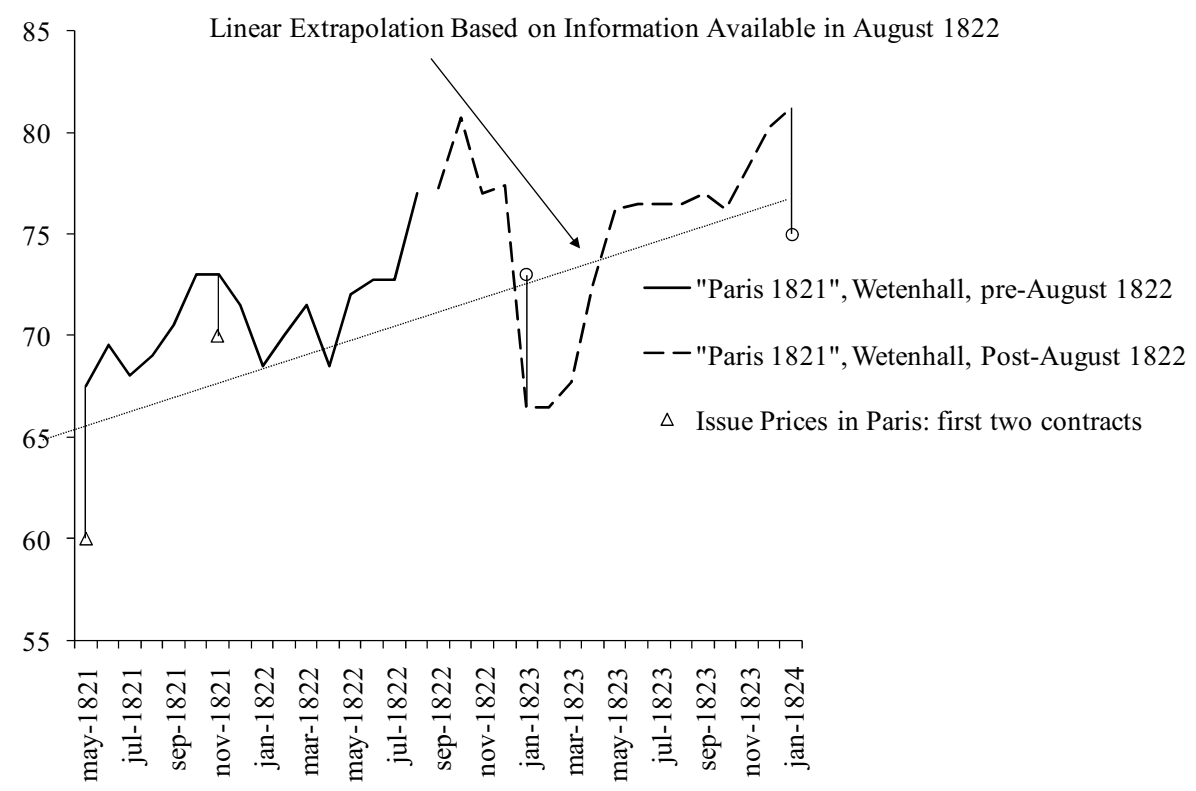

FIGURE 5

SPOT PRICES OF NEAPOLITAN RENTES IN LONDON 1821-1824

TRENDS AND ISSUE PRICES

Sources: Wetenhall, Course of Exchange; and Cours des effets commerçables à la Bourse de Paris.

for their reputation, prestigious underwriters offered extensive post-issue insurance services that were only feasible because of their enormous capital. $^{73}$

\section{An Equilibrium for Intermediaries, Investors, and Borrowers}

Clearly, intermediaries, investors, and borrowers found rewards in this system. Consider first the banks, for which we have gathered evidence for the period 1822-1840. Good banks, we argue, had all reasons to be careful regarding the instruments they would bring to the market after the collapse of 1825. The Rothschilds' careful selection and Barings' wait and see

maneuvering: Naples was financing military occupation by Austria, and the Vienna branch was trying to persuade Metternich to put an end to the occupation in order to alleviate Naples' financial burden.

${ }^{73}$ Gille, Rothschild, vol. I., p. 163, emphasizes the importance of liquidity. Gille, Rothschild, vol. I., p. 165, also describes how the Rothschilds clustered various layers of investors according to their appetite for risk and could involve clients at various stages as needed. 
enabled both to remain in the market consistently. Other banks, by contrast, cashed fees for those securities they managed to sell and then often dropped out. Of the ten banks (besides Rothschilds and Barings) that were involved in the foreign debt boom of $1822-1825$, we find that two went bust and six withdrew during the subsequent period (1826-1840). Finally, three houses entered the sovereign debt market for the first time after 1826. Such "wildcats" underwriters came and went. ${ }^{74}$

What about investors? During the 1820 s investing a prestigious underwriter meant huge gains. Earlier historians have emphasized that Rothschilds managed the portfolios of the super rich of the day. The Rothschilds' investments resembled the so-called "convergence plays" that modern investment banks undertook on emerging markets sovereign debt instruments in the first half of the current decade, and like these, they were very profitable. The run-ups of Rothschild IPOs rewarded the bank's inner circle of investors handsomely. They bought the Neapolitan "rescue" of 1823 at 73 , and could sell it five months later at 76.25 , a 9 percent annualized return. ${ }^{75}$ The Rothschilds' operations may be said to have pioneered the actions of modern hedge funds with their sheer size and ambitious bets. Capital, again, mattered.

What about borrowers? Large Rothschild run-ups amounted to money left on the table, so governments were probably not too happy. But they had no alternative. Using other houses would mean a bad signal to the market and a risk of failure. Furthermore, as Figure 6 shows, these costs diminished over time. Having successfully brought a new borrower to the market, the Rothschilds now had to take lower margins, for they had revealed the issuer's worth and thus eroded their own monopoly power. Of course, they still did retain a lead that enabled them to defeat competitors in open auctions, because the signals sent by their competitors were not as good as the ones they could send.

The result was an incentive system that shifted rewards from good behavior to the future while imposing short-term costs; it can be interpreted as a mechanism that encouraged borrowers to reveal their true worth. In a period of market euphoria, when liquidity was abundant, a non-serious borrower would be deterred by the high access costs charged

\footnotetext{
${ }^{74}$ The two banks that managed to remain in the sovereign debt business past 1825 were the Wilsons and Ricardo. None of Wilson's earlier issues had defaulted and so its continued participation is understandable. Ricardo, the underwriter with the highest yield at issue before 1825 (about 600 basis points), managed to introduce several loans during the second period, again at discount prices (above 600 basis points). Ricardo was an avowed seller of junk bonds. It is a form of honesty.

${ }^{75}$ Another case for which we could compute gains is the Brazilian rescue operation of May 1829, where the Rothschilds let the Wilsons act as underwriters and issuers but took over most of the subscription. If the securities were sold in December at the market price and held, investors would gain above 40 percent.
} 


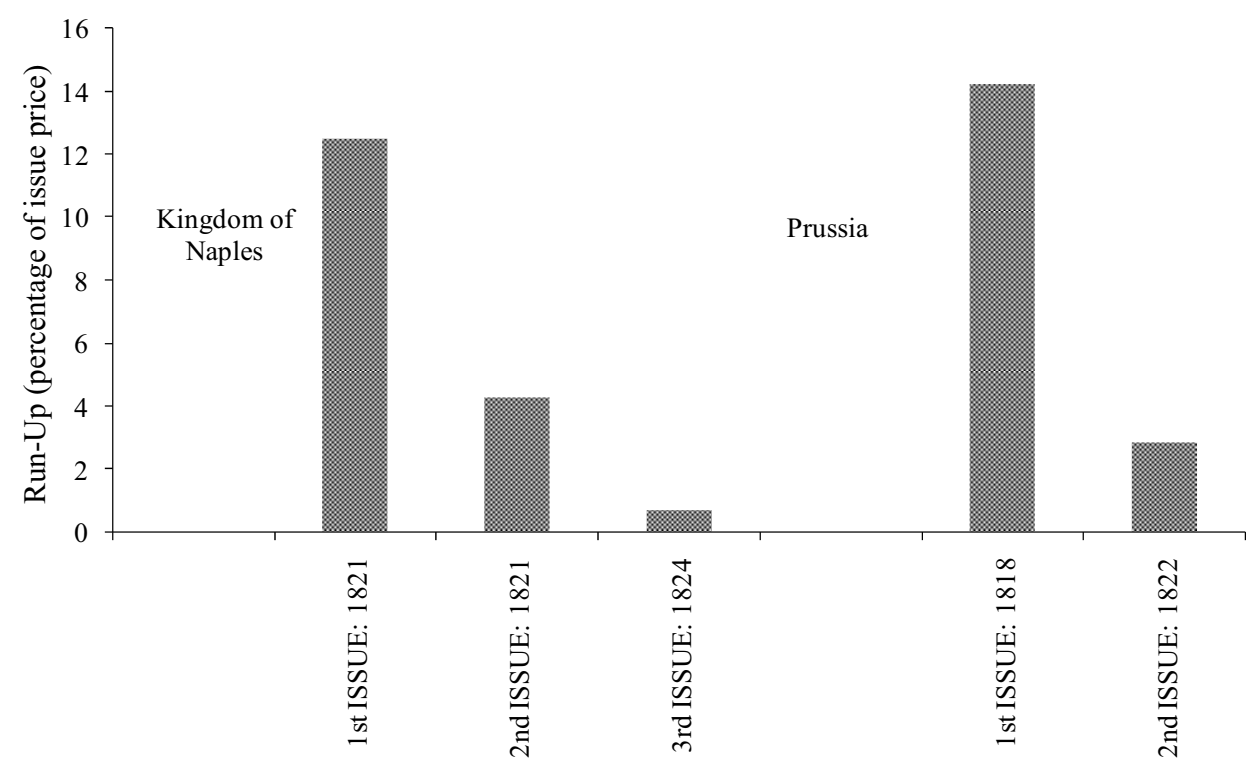

FIGURE 6

PRICE RUN-UPS IN MAIDEN AND SEASONED ISSUES, NAPLES AND PRUSSIA

Note: Neapolitan forward contracts discussed earlier are excluded from this chart for obvious reasons

Source: The authors' computations.

by a prestigious firm like Rothschilds. Such a borrower would prefer to go to another, less prestigious bank, which would sell at a lower run-up and higher price. By contrast, employing the Rothschilds meant heavy upfront costs but also long-run benefits.

The 1823 Portuguese loan is illuminating here. The Rothschilds approached the government of Portugal and made an offer and so did B. A. Goldschmidt. According to the contracts however, Rothschilds' IPO price was almost 20 percent lower than that offered by the House of Goldschmidt, which eventually won the deal. ${ }^{76}$ Using the fitted relation between the spread at issue and the IPO run ups in Figure 4, we can predict that Rothschilds' issue would have had a 6 percent run-up (Figure 7): Portuguese bonds would have risen to 77.75 (or a yield of 6.5 percent) on the first day of trading. That is much lower than Goldschmidt's price, which suggests that the higher issue price set by the House of Goldschmidt was not sustainable. Predictably, Goldschmidt had to push

\footnotetext{
${ }^{76}$ That is, Rothschild offered to issue at 73; Rothschild Archive 000/401 A. There was also a commission of 3 percent. B. A. Goldschmidt brought the issue at 87 . We do not know the Goldschmidt commission.
} 


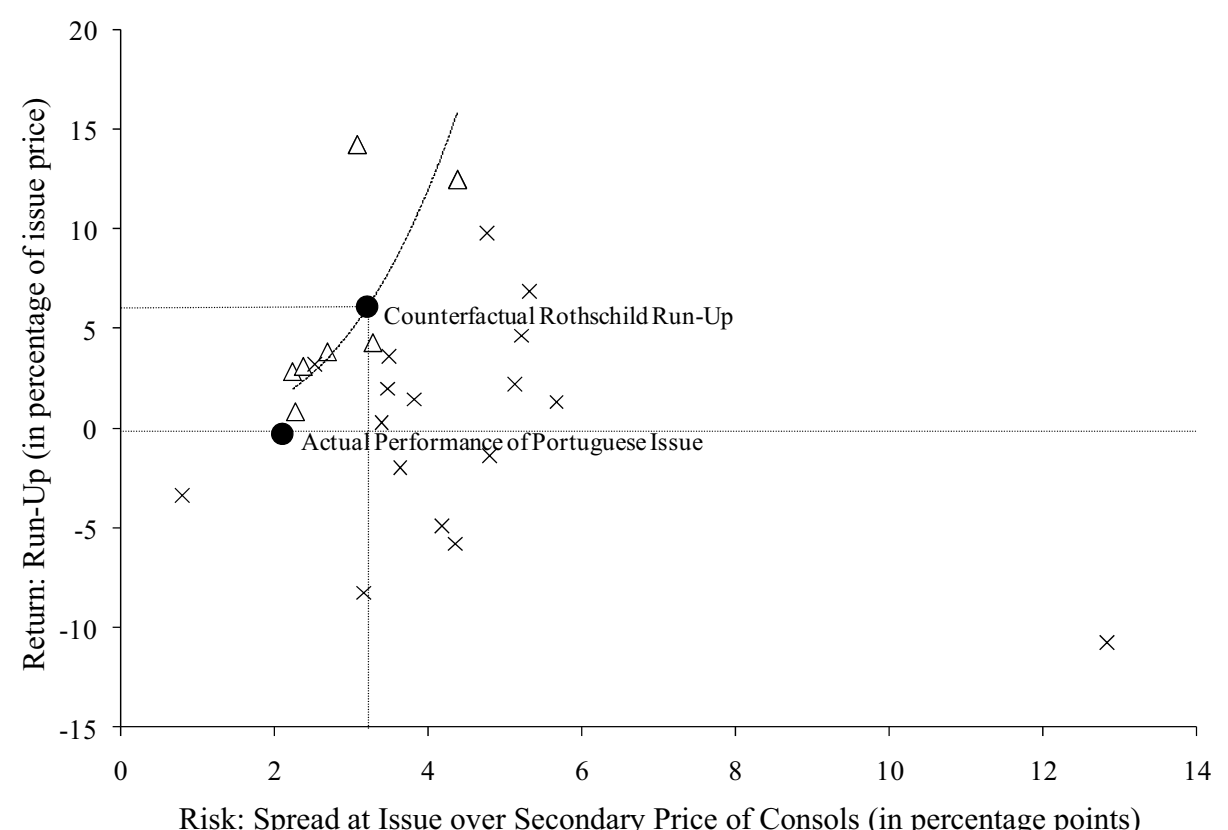

FIGURE 7

A COUNTERFACTUAL: PORTUGAL 1823

Source: Authors' computations from Wetenhall, Course of Exchange; and Rothschild Archive.

the price up through heavy market purchases, thus going long on Portuguese bonds. When the general decline began, it was caught wrong footed, and that contributed to the bank's downfall in February 1826. At that date, Portugal traded at 73, which was ironically Rothschild's IPO price. Portugal's decline continued beyond that point until it eventually defaulted. It is likely that a good borrower with a longer time horizon would have accepted Rothschild's apparently stricter offer - and would also later have enjoyed market support and sustained market access.

\section{UNDERWRITERS, INFORMATION, AND CONTAGION: A TEST}

And thus it is that bonds issued by Rothschilds were successes while bonds issued by ordinary houses were failures. Rothschild securities became a brand. In effect, a transfer of reputation from the intermediary to the borrower had occurred. Austrian Ambassador Charles Louis de Ficquelmont reported to Metternich in February 1822 on the causes of the surge of Neapolitan bond prices: "And thus it is that the credit of a foreigner, which is to say that of the House of Rothschild, not that of the Kingdom of Naples, was responsible for the rise of Neapolitan 
securities . ..."77 Popular stock market sources such as is reproduced in Figure 3 therefore contained the right amount of information: they said that Goldschmidt had underwritten Portugal, while Rothschild had underwritten Naples, and that was enough for investors. The underwriter was the fundamental.

Contemporaries recognized that, and information on prestigious banks' actions became a market driver. ${ }^{78}$ People trading on volatility remarked that the number of messengers received by the House of Rothschild was a signal of impeding market movements. In Frankfurt, a "mini-crash" was triggered in April 1822 by the arrival of an unusual number of Rothschilds' couriers. ${ }^{79}$ In Naples, messengers had to change clothing to avoid disrupting the market. Speculators tried to plant rumors about the Rothschilds, which they denied, clarified, or ignored. A whole business of information collection, retention, and distribution was born, and its focal point was not what the borrowers were doing but the actions of intermediaries.

These considerations provide a motivation for a final test of the views articulated in this article. We have seen that there were essentially two types of intermediaries: "value rich" intermediaries, who signaled investment grade (essentially Rothschilds, since Barings abstained), and "value poor" intermediaries, who signaled a junk bond. If our view is correct, then we should observe certain patterns of co-movement among bonds spreads in the two groups. The spreads of countries' bonds underwritten by ordinary (value poor) banks should be strongly correlated with one another, but weakly correlated with the spreads of bonds underwritten by prestigious (value rich) ones. We also expect less co-movement among bonds underwritten by prestigious banks, since prestigious underwriters are able to signal finer quality shades. The test we consider looks at empirical data to see whether these predictions are borne out, distinguishing between Rothschild countries and nonRothschild ones.

There are various ways to measure co-movements. For simplicity, (and while we realize this method has limitations) this section adopts the methodology in P. Mauro, N. Sussman, and Y. Yafeh, which focuses on commonality of extreme events or "sharp changes" in bond

\footnotetext{
${ }^{77}$ Gille, Rothschild, vol. I., p. 98

${ }^{78}$ This interpretation is consistent with Gille, Rothschild, vol. I., p. 166; Moniteur universel 22 September 1826; and Journal du Commerce, 23 September 1826.

${ }^{79}$ Gille (Rothschild, vol. I., p. 188); and Journal du Commerce (3 April 1822). See also Gille (Rothschild, vol. I., p. 167).
} 
TABLE 5

SHARP CHANGES WITHIN DIFFERENT GROUPS OF BORROWERS $(1822-1829)$

\begin{tabular}{|c|c|c|c|c|}
\hline Periods & \multicolumn{2}{|c|}{ Non-Rothschild Group } & \multicolumn{2}{|c|}{ Rothschild Group } \\
\hline & \multicolumn{4}{|c|}{ Sharp Changes Within and Between Groups } \\
\hline & $\begin{array}{l}200 \text { basis } \\
\text { points }\end{array}$ & $20 \%$ & $\begin{array}{l}200 \text { basis } \\
\text { points }\end{array}$ & $20 \%$ \\
\hline & Within $\mathrm{Nc}$ & hschild & Within & hild \\
\hline \multirow{2}{*}{$\begin{array}{l}\text { Sharp changes in percent of total } \\
\text { observations }\end{array}$} & 10.5 & 7.6 & 0.0 & 2.5 \\
\hline & \multicolumn{4}{|c|}{ Proportion of Months with Characteristics Listed } \\
\hline No sharp changes & 37.2 & 45.7 & 100.0 & 90.4 \\
\hline $\begin{array}{l}\text { Sharp changes in exactly one } \\
\text { country }\end{array}$ & 20.2 & 25.5 & 0.0 & 8.5 \\
\hline $\begin{array}{l}\text { Sharp changes in exactly two } \\
\text { countries }\end{array}$ & 16.0 & 11.7 & 0.0 & 0.0 \\
\hline \multirow{2}{*}{$\begin{array}{l}\text { Sharp changes in three countries } \\
\text { or more }\end{array}$} & 26.6 & 8.5 & 0.0 & 1.1 \\
\hline & \multicolumn{4}{|c|}{ Contagion Ratio } \\
\hline $\begin{array}{l}\text { Number of sharp changes in more } \\
\text { than one country to number of } \\
\text { sharp changes in at least one } \\
\text { country }\end{array}$ & 67.8 & 44.2 & n.a.* & 11.1 \\
\hline
\end{tabular}

* When there are no sharp changes to begin with, the contagion ratio is meaningless.

Note: In order to identify common sharp changes, individual series must be complete and cover the same time period. As a result, Rothschild countries are Russia, Prussia, and Naples. NonRothschild countries are Chile, Colombia, Peru, and Spain.

Source: Authors' computations using Wetenhall, Course of Exchange.

spreads. Sharp changes are defined as monthly variations of more than 200 basis points (say, an increase from 9 to 11 percent) or, alternatively, more than 20 percent (say an increase from 9 to 10.8 percent). Common sharp changes in the spreads of different countries' bonds imply that a common "contagious" factor is at work. We apply this framework to determine whether there was contagion and what its source was during the period 1822-1829.

Table 5 shows that sharp changes were much more frequent for non-Rothschild countries than for Rothschild countries. Second, we see that contagion tended to cluster in the non-Rothschild group. The contagion ratio (the ratio of sharp changes in more than one country to sharp changes in at least one country) is very high for the nonRothschild group, but very low for the Rothschild group (in fact, it 
cannot be computed for the 200 basis points in the Rothschild group for sheer lack of such events).

We then computed (but did not report in Table 5) the conditional probability of at least one sharp change occurring in the Rothschild group conditional on a sharp change occurring in the non-Rothschild group. In the only case for which it can be meaningfully computed (the 20 percent variation case), this probability is 13.9 percent. This stands against the non-conditional probability of a sharp change in the Rothschild group, which Table 5 gives as 9.6 percent $(=100-90.4)$. A sharp change in a non-Rothschild bond spread did increase the probability of Rothschild countries' sharp changes, but the infection was limited.

Our interpretation of these results is that when investors observed an event affecting a country underwritten by an ordinary intermediary, they thought that it was relevant for other countries underwritten by other ordinary intermediaries, but not for countries underwritten by Rothschilds. There are two possible reasons for this way of thinking. Either investors expected prestigious banks to sell prime securities, so that they could ignore information coming from the market for ordinary government debt. Alternatively, they expected these banks to intervene in the open market in support of their customers (as we have seen was the case for Naples). The Rothschild brand was thus both insurance against sharp price changes and a sorting device that enabled countries - with or without a parliament - to avoid contagion. That possibility could not have escaped the attention of Metternich, architect of the Holy Alliance.

\section{CONCLUSION: BEYOND DEMOCRATIC ADVANTAGE}

Our article has dealt with the development of a sustainable market for sovereign debt in the early nineteenth century. It revolves around a simple idea. The system rested on a transfer of credibility from the underwriter to the borrower. Investors could not learn about borrowers, but they could learn about underwriters. Prestigious underwriters came to monopolize the market for good sovereign debt. Lower quality intermediaries tried and did occasionally break in but their involvement signalled higher risks. Investors got the message, and the market for bad debt collapsed and did not resume for a while. We conclude that hierarchy among intermediaries offered a remedy against what theoreticians call the "contracting" and "collective action" externalities in sovereign debt. The early-nineteenth-century international financial architecture provides a fascinating case of how 
"governance without government" may look. It rested on an intriguing form of market conditionality made possible by the monopoly power of leading underwriters. ${ }^{80}$

Our analysis has implications for future research. One is that fiscal checks and balances can be found in places other than domestic political institutions. We recognize that it is sometimes possible to monitor government satisfactorily by giving parliament a veto point over the executive. We also realize that this may be desirable. But other monitoring devices exist, and the quality of financial intermediaries provides an example.

What then was needed for sovereign borrowing to occur? From our perspective, the answer is this: adequate borrowers were not necessarily those with constitutions and commitments. Those who could implement the policy adjustments that monopolist underwriters would require were also eligible. ${ }^{81}$

This line of reasoning suggests that the quality of the administrative apparatus and centralization of decision making were critical elements for access to external funding. From the vantage point of administrative robustness and centralized decision making, Brazil, the Kingdom of Naples, Prussia, Austria, and Russia all had something in common: they were not all parliamentary countries, but they were all described as strong, centralized states.

The development of sovereign lending in the nineteenth century was collateralized by robust administrative infrastructures. Strong and reactionary governments were allowed to borrow, even if they lacked domestic constitutional constraints, precisely because they were strong. There was no bias in favor of borrowers who were democratic or supported the rule of law. But there was a bias in favor of arch-conservatives who had no remorse about implementing unpopular policies or even ruthless repression. This somewhat frightening conclusion is antithetic to the "democratic advantage" view, which neo-institutionalists have recently emphasized. ${ }^{82}$

\footnotetext{
${ }^{80}$ Rosenau, Governance.

${ }^{81} \mathrm{We}$ do not think of our new hypothesis as necessarily exclusive to that of North and Weingast. The case of Denmark is a reminder.

82 Schultz and Weingast, "Democratic Advantage."
} 


\section{REFERENCES}

Allen, F., and G. Faulhaber. "Signalling by Underpricing in the IPO Market." Journal of Financial Economics 23, no. 2 (1989): 303-23.

Beatty R., and J. Ritter. "Investment Banking, Reputation, and the Underpricing of Initial Public Offerings." Journal of Financial Economics 15, no. 1-2 (1986): 213-32.

Borchard, E. State Insolvency and Foreign Bondholders, Vol. 1: General Principles. New Haven, CT: Yale University Press, 1951.

Bordo, M., and H. Rockoff. "The Gold Standard as a Good Housekeeping Seal of Approval." This JouRnAL 56, no. 2 (1995): 389-428.

Buckle, W. F., and G. E. Monnypenny. The Life of Benjamin Disraeli, Earl of Beaconsfield. New York: Russell and Russell, 1968.

Buist, M. G. At Spes non fracta: Hope \& Co, 1770-1815, Merchant Bankers and Diplomats at Work. Bank Mees \& Hope N.v., 1974.

Bulow, J., and K. Rogoff. "A Constant Recontracting Model of Sovereign Debt." Journal of Political Economy 97, no. 1 (1989): 155-78.

. "Sovereign Debt: Is to Forgive to Forget?" American Economic Review 79, no. 1 (2007): 43-50.

Carey, G. G. Every Man his own Stock-broker; or, a Complete guide to the public funds: with the manner of transferring stock, etc. London: J. Johnston, 1820.

Every Man his own stock-broker, or, A complete guide to the public funds: with the manner of transferring stock: rules . . . to which are added rules for standarding gold and silver coins and bullion, and for calculating its value: with extensive tables of the value, weight, and fineness of the current gold and silver coins of the principal countries in the world. London: J. Johnston, 1821.

. [probably], Every Man his own stock-broker, A New guide to the public funds, or, Every man his own stock-broker: containing the origin of the funding system, causes of the fluctuation of the prices of stocks, manner of transferring stock. London: D. B. Woodward, 1825.

Carosso, V. The Morgans: Private International Bankers, 1853-1913. Cambridge: Harvard University Press, 1988.

Carter, R. B., F. H. Dark, and A. K. Singh. "Underwriter Reputation, Initial Returns, and the Long-Run Performance of IPO." Journal of Finance 53, no. 1 (1998): 285-311.

Carter, R. B., and S. Manaster. "Initial Public Offerings and Underwriter's Reputation." Journal of Finance 45, no. 4 (1990): 1045-67.

Cassis, Y. "The Emergence of a New Financial Institution." In Capitalism in a Mature Economy: Financial Institutions, Capital Exports, and British Industry, 1870 1939, edited by J. J. van Helten and Y. Cassis, 39-158. Aldershot, UK: Edward Elgar, 1990.

Chapman, S. The Rise of Merchant Banking. London: George Allen and Unwin, 1984.

Chemmamur, T. J. "The Pricing of Initial Public Offerings: A Dynamic Model with Information Production.” Journal of Finance 48, no. 1 (1993): 285-304.

Chemmanur, T. J., and B. Fulghieri. "Investment Bank Reputation, Information Production, and Financial Intermediation.” Journal of Finance 49, no. 1 (1994): 57-79.

Chowdry, B. "What is Different About International Lending?" Review of Financial Studies 4, no. 1 (1991): 121-48.

Corporation of Foreign Bondholders. Annual Reports, 1873-1878. 
Corti, E. C. The Reign of the House of Rothschild. London: V. Gollancz, 1928.

Costeloe, M. P. Bonds and Bondholders: British Investors and Mexico's Foreign Debt, 1824-1888. Westport, CT: Praeger, 2003.

Cours des effets commerçables à la Bourse de Paris, 1820-1829.

Dawson, F. G. The First Latin American Debt Crisis: The City of London and the 1822-1825 Loan Bubble. Princeton, NJ: Princeton University Press, 1990.

DeLong, J. B. “Did J. P. Morgan's Men Add Value? An Economist's Perspective on Financial Capitalism." In Inside the Business Enterprise: Historical Perspectives on the Use of Information, edited by Peter Temin, 205-36. Chicago: University of Chicago Press, 1991.

Diamond, D. W. "Reputation Acquisition in Debt Markets." Journal of Political Economy 97, no. 4 (1989): 828-62.

Doubleday, T. A Financial, Monetary, and Statistical History of England, from the Revolution of 1688 to the Present Time. London: Effingham Wilson, Royal Exchange, 1847.

Dwyer, G. P. "Wildcat Banking, Banking Panics, and Free Banking in the United States." Federal Reserve Bank of Atlanta Economic Review 81 (1996): 1-20.

Eichengreen, B., and R. Portes. "After the Deluge: Default, Renegotiation, and Readjustment in the Interwar Years." In The International Debt Crisis in Historical Perspective, edited by B. Eichengreen and P. Lindert, 12-47. Cambridge, MA: MIT Press, 1989.

. "Settling Defaults in the Era of Bond Finance." World Bank Economic Review 3, no. 2 (1989): 211-39.

Esteves, R. P. "Quis custodiet quem? Sovereign Debt and Bondholders' Protection Before 1914.” Working Paper No. 323, Oxford University, 2007.

Euronext Archive, Paris.

Ferguson, N. The World's Banker. London: Weidenfeld and Nicholson, 1998.

Ferns, H. S. Britain and Argentina in the Nineteenth Century. Oxford: Claredon Press, 1960.

Flandreau, M. "Caveat Emptor: Coping with Sovereign Risk Under the International Gold Standard, 1871-1913." In The International Financial History in the Twentieth Century: System and Anarchy, edited by M. Flandreau, C.-L. Holtfrerich, and H. James, 17-50. Cambridge: Cambridge University Press, 2003. . "Crises and Punishment: Moral Hazard and the Pre-1914 International Financial Architecture." In Money Doctors: The Experience of International Financial Advice, 1850-2000, edited by M. Flandreau. London: Routledge, 2003.

. The Glitter of Gold. France, Bimetallism and the Emergence of the International Gold Standard, 1848-1873. Oxford: Oxford University Press, 2004.

"Home Bias, Nineteenth-Century Style." Journal of the European Economic Association 4, no. 2-3, (2006): 634-43.

Flandreau, M., and F. Zumer. The Making of Global Finance. Paris: OECD, 2004.

Flores, J. Lorsque le leader suit la foule: La crise baring dans une perspective microéconomique. Unpublished Dissertation, Sciences Po, Paris, 2004.

"Capital Flows to Emerging Markets: When Lombard Street is a Career." Mimeo, Chaire finances internationals, 2005.

"Lending Booms, Underwriting, and Competition: The Baring Crisis Revisited." Working Papers in Economic History, Universidad Carlos III, 07-01, 2007. 
"Information Asymmetries and Financial Intermediation During the Baring Crisis: 1880-1890." Working Papers in Economic History, Universidad Carlos III, 07-16, 2007.

Fodor, G. "The Boom That Never Was? Latin American Loans in London, 18221825." Working Paper, University of Trento, 2002.

Fortune, T. An Epitome of the Stock and Public Funds [. . .] together with an Appendix containing the first account ever published here of the Bank Stock and Funds of the United States of America, 8th edition. London: T. Boosey, 1810.

. Fortune's Epitome of the Stocks and Public Funds; containing every necessary information for perfectly understanding the nature of those securities, and the mode of doing business therein: with a full account of the Bank stocks and funds of the United States of America, and also of all the other foreign funds. 11th edition. London: T. Boosey, 1824.

Fortune's Epitome, [A Member of the Stock Exchange, J. G. Dessoulavy, Stock Broker Bank Coffee House], Fortune's Epitome of the Stocks and Public Funds . . . A Full account of the Bank Stocks and Funds of the United States of American and also of the French Funds, 10th edition. London: Boosey and Sons, 1820.

Fulford, R. Glyn's 1753-1953, Six Generations in Lombard Street. London: Macmillan, 1953.

Gilbart, J. W. The History and Principles of Banking. 3rd edition. London: Longman, 1837.

Gille, B. Histoire de la Maison Rothschild, Vol I: Des origines à 1848. Geneva: Droz, 1965.

. Histoire de la Maison Rothschild, Vol II: 1848-1870. Geneva: Droz, 1967.

Gorton, G. "Reputation Formation in Early Banknotes Markets." Journal of Political Economy 104, no. 2 (1996): 346-97.

Great Britain Parliament, House of Commons. Select Committee on Loans to Foreign States Special report and report from the Select Committee on Loans to Foreign States, 1875 with proceedings, minutes of evidence, appendix and index. Shannon: Irish University Press, 1969.

Guildhall Library, London.

Hayes, S. "Investment Banking: Power Structure in Flux." Harvard Business Review 49, March-April (1971): 136-52.

Hidy, R. W. The House of Baring in American Trade and Finance: English Merchant Bankers at Work, 1763-1861. Cambridge: Cambridge University Press, 1949.

Hoffman, P., G. Postel-Vinay, and J.-L. Rosenthal. Surviving Large Losses. Cambridge, MA: Harvard University Press, 2007.

Ibbotson, R. "Price Performance of Common Stocks New Issues." Journal of Financial Economics 2, no. 3 (1975): 235-72.

ING-Baring Archive, London.

Jenks, L. H. The Migration of British Capital to 1875. London: Thomas Nelson, 1927.

Kehr, E. "Zur Genesis der preussichen Bürokratie und des Rechtaats." In Der primat der Innenpolitik, edited by H.-U. Wehler, 31-52. Berlin: Walter de Gryuter, 1970.

Landes, D. Bankers and Pashas, International Finance and Economic Imperialism in Egypt. London: Heinemann, 1958.

Lewis, C. America's Stake in International Investments. Washington, DC: The Brookings Institution, 1938. 
Lipson, C. "International Debt and National Security: Comparing Victorian Britain and Postwar America." In International Debt in Historical Perspective, edited by B. Eichengreen and P. Lindert, 189-226. Cambridge, MA: MIT Press, 1989.

Logue, D. "On the Pricing of Unseasoned Equity Issues: 1965-1969." Journal of Financial and Quantitative Analysis 8, no. 1 (1973): 91-103.

Marichal, C. A Century of Debt Crises in Latin America: From Independence to Great Depression, 1820-1930. Princeton, NJ: Princeton University Press, 1989.

Mathew, W. M. "The First Anglo-Peruvian Debt and Its Settlement, 1822-1849." Journal of Latin American Studies 2, no. 1 (1970): 81-98.

Mauro, P., N. Sussman, and Y. Yafeh. Emerging Markets and Financial Globalization: Sovereign Bond Spreads in 1870-1913 and Today. Oxford: Oxford University Press, 2006.

Megginson, W., and K. Weiss. "Venture Capitalists Certification in Initial Public Offerings." Journal of Finance 46, no. 3 (1991): 879-903.

Michaely, R., and W. H. Shaw. "The Pricing of Initial Public Offerings: Tests of Adverse Selection and Signaling Theories." The Review of Financial Studies 7, no. 2 (1994): 279-310.

Miller, R., and F. Reilly. "An Examination of Mispricing, Returns, and Uncertainty for Initial Public Offerings." Financial Management 16, no. 2 (1987): 33-38.

Mintz, I. Deterioration in the Quality of Foreign Bonds Issued in the United States, 1920-1930. New York: National Bureau of Economic Research, 1951.

Mitchener, K. J., and M. Weidenmier. "Empire, Public Goods, and the Roosevelt Corollary." This JOURNAL 65, no. 3 (2005): 658-92.

."Supersanctions and Sovereign Debt Repayment." NBER Working Paper No. 11472, Cambridge, MA, 2006.

Mortimer, T. Every Man his own Broker, or, A guide to Exchange-Alley: in which the nature of the several funds, vulgarly called the stocks, is clearly explained: and the mystery and iniquity of stock-jobbing laid before the public in a new and impartial light: also the method of transferring stock . . to which is added, new tables of interest, First edition, London: Printed for S. Hooper, 1761.

Mosley, L. Global Capital and National Governments. Cambridge: Cambridge University Press, 2003.

Neal, L. The Rise of Financial Capitalism: International Capital Markets in the Age of Reason. New York and Cambridge: Cambridge University Press, 1991.

. "The Financial Crisis of 1825 and the Restructuring of the British Financial System." Review, Federal Reserve Bank of St. Louis (May 1998): 53-76.

Nicolle, A. "Ouvrard and the French Expedition in Spain in 1823." Journal of Modern History 17, no. 3 (1945): 193-201.

North, D. C., and B. R. Weingast. "Constitutions and Commitment: The Evolution of Institutions Governing Public Choice in Nineteenth-Century Britain." This JOURNAL 49, no. 4 (1989): 803-32.

Platt, D. C. M. Finance, Trade, and Politics in British Foreign Policy, 1815-1914. London: Clarendon Press, 1968.

"Foreign Finance in Argentina for the First Half-Century of Independence." Journal of Latin American Studies 15, no. 1, (May 1983): 23-47.

Polanyi, K. The Great Transformation: The Political and Economic Origin of Our Times. Boston: Beacon Press, 1944.

Razaghian, R. "Establishing Financial Credibility in the United States, 1789-1860." Mimeo, Yale University, 2004. 
Riley, J. C. International Government Finance and the Amsterdam Capital Market, 1740-1815. Cambridge and New York: Cambridge University Press, 1980.

Ritter, J. "The 'Hot Issue' Market of 1980." The Journal of Business 57, no. 2 (April 1984): 215-40.

"The Costs of Going Public." Journal of Financial Economics 19, no. 2 (1987): 269-82.

Roberts, R. Shroders: Merchants and Bankers. Basingstoke: Macmillan, 1992.

Rock, K. "Why New Issues are Underpriced?" Journal of Financial Economics 15, no. 1-2 (1986): 187-212.

Root, H. "Institutions, Interest Groups, and Authority in Ancien Régime France." French History 6, no. 4 (1992): 411-34.

Rosenau, J. N. Governance Without Government: Order and Change in World Politics. Cambridge and New York: Cambridge University Press, 1992.

Rothschild Archive, London.

Schultz, K. A., and B. R. Weingast. "The Democratic Advantage: Institutional Foundations of Financial Power in International Competition." International Organization 57 (Winter 2003): 3-42.

Stasavage, D. Public Debt and the Birth of the Democratic State: France and Great Britain, 1688-1789. Cambridge: Cambridge University Press, 2003.

"Partisan Politics and Public Debt: The Importance of the 'Whig Supremacy' for Britain's Financial Revolution." European Review of Economic History II, (2007): 123-53.

Summerhill, W. "Sovereign Commitment and Financial Underdevelopment in Imperial Brazil." Working Paper, University of California, Los Angeles, 2006.

Sussman, N., and Y. Yafeh. "Institutions, Reforms, and Country Risk: Lessons from Japanese Government Debt in the Meiji Era." This JOURnAL 60, no. 2 (2000): 442-67.

Sutton, J. "Market Structure: Theory and Evidence." Mimeo, London School of Economics, 2006.

Suzuki, T. Japanese Government Loan Issues on the London Capital Market, 1870 1913. London: Athlone Press, 1994.

Sylla, R. "An Historical Primer on the Business of Credit Rating." In Ratings, Rating Agencies, and the Global Financial System, edited by Richard Levich, Giovanni Majnoni, and Carmen Reinhart, 19-40. Boston: Kluwer Academic Press, 2002.

The Times, various issues, 1818-1830.

Tomz, M. Reputation and International Cooperation: Sovereign Debt Across Three Centuries. Princeton, NJ: Princeton University Press, 2007.

Vizcarra, C. "Guano, Credible Commitments, and State Finance in NineteenthCentury Peru." Mimeo, University of Vermont, 2006.

Wetenhall, James. The Course of the Exchange, 1818-1830. Kew, UK: The National Archives.

Wiener Zeitung, various issues, 1823-1829.

Winkler, M. Foreign Bonds: An Autopsy. New York: Arno Press, 1976.

Wright, M. "Reputations and Sovereign Debt." Mimeo, Stanford University, 2002.

Wynne, W. H. State Insolvency and Foreign Bondholders, Vol. 2: Selected Case Histories of Governmental Bond Defaults and Debt Readjustments. New Haven, CT: Yale University Press, 1951.

Ziegler, P. The Sixth Great Power: Barings, 1762-1929. London: Collins, 1988. 